\title{
A Resource-based Paradigm of Entrepreneurship: The Optimal Organization of Entrepreneurs as Resource
}

\author{
Brian Barnard ${ }^{1}$, Derrick Herbst ${ }^{2}$ \\ ${ }^{1}$ Wits Business School, University of Johannesburg, Johannesburg, South Africa \\ ${ }^{2}$ Henley Business School South Africa, University of Reading, Johannesburg, South Africa \\ Correspondence: Derrick Herbst, Henley Business School South Africa, University of Reading, Johannesburg, South \\ Africa; Brian Barnard, Wits Business School, University of Johannesburg, Johannesburg, South Africa.
}

Received: April 23, 2017

doi:10.11114/bms.v3i2.2375

\author{
Accepted: May 30, $2017 \quad$ Online Published: May 30, 2017 \\ URL: https://doi.org/10.11114/bms.v3i2.2375
}

\begin{abstract}
The study examines entrepreneurs as resource, with emphasis on the entrepreneur as professional. It concludes that entrepreneurs are reliable - they are able to repeatedly innovate and venture; universal - they are not necessarily bound by industry; and experts and professionals that specialize in an area of expertise. The factors that contribute to their reliability, universality, and expertise are noted. In addition, the necessary qualifications of an entrepreneur, their development, and the factors that impact their efficiency were also investigated. It is found that entrepreneurs develop with time. By considering what motivates them, and their area of speciality, the extent by which entrepreneurs can be managed, and their authority and sphere of influence are examined.
\end{abstract}

The possible ways of organizing entrepreneurs were considered, contrasting between the objectives of the entrepreneur and that of his organization. In this regard, the key aspects were: i) funding, ii) resources, iii) risk and reward sharing, and iv) opportunity recognition and development.

The results raise investment culture, together with policies towards failure. The resources important for entrepreneurship are listed, as well as the factors relevant to venture success, and how this influences the organization of entrepreneurs. The benefits and also the hinderances of institutions, collaborative groups and entrepreneurs as individuals were considered. The informal and humanistic nature of networks surfaced, together with their competing method of opportunity appraisal, with more emphasis on the entrepreneur and other humanistic factors. Large organizations enabling entrepreneurship in small organizations (corporate venturing) surfaced as one of the optimal ways to organize entrepreneurs. Furthermore, given their characteristics, entrepreneurs can be readily exploited as economical and societal resource, with perhaps less cost than believed. It is found that the relationship between entrepreneurial throughput and risk and reward may be overlooked, lacking substance, and subject to stereotypical thinking. Entrepreneurial reward ignores entrepreneurial throughput, or assumes that entrepreneurial throughput is maximized through maximizing entrepreneurs' rewards. Risk minimization, particularly for the entrepreneur, is also not necessarily related to entrepreneurial throughput.

The study raises a number of factors and deficiencies that impact entrepreneurial output. In view of this, a number of constructs and measures pertaining to entrepreneurship are suggested: i) entrepreneurial emergence - the method used to identify entrepreneurs, and the rate at which new entrepreneurs are identified; ii) entrepreneurial development - the growth and development of known entrepreneurs; iii) entrepreneurial longevity - the reuse and lifespan of entrepreneurs; and iv) the evaluation of entrepreneurs.

The interaction between entrepreneurs and the needs of entrepreneurs also surfaced - most notably unbiased support, which they source through support networks or "entrepreneurial fraternities". Motivation and encouragement may be as valuable advice as professional views and opinions. The study ends by raising the question whether it would indeed be possible to institutionalize entrepreneurship, mostly through legislation that require organizations to spend a percentage on entrepreneurship. A number of points support this line of thinking.

Keywords: entrepreneurship, resource, human resource, organization 


\section{Introduction}

\subsection{Entrepreneurship in Overview}

Cunningham and Lischeron (1991) list the schools of thought on entrepreneurship as: 1) "Great Person" School, 2) Psychological Characteristics School, 3) Classical School, 4) Management school, 5) Leadership school, 6) Intrapreneurship school.

The venture evaluation criteria delineated by Tyebjee \& Bruno (1984), and MacMillan et al (1985) evolve around a) leadership and management, b) product and market, c) capabilities and competencies, and d) risk. From these tables it is clear that skill, competency, and management are seen as some the factors of success of entrepreneurship, and the purpose of the entrepreneur is to identify opportunities, to articulate them, to manage their development, and to reduce the associated risk to a minimum. Entrepreneurs are knowledgable, experienced and informed, and the result is a venture that is well-positioned within its market, and adequately shielded from competition. From the tables it also becomes clear that venture capitalists - or simply the venture investors - may have a strong say in the selection and development of ventures overall.

Within innovation as discourse, and extended to corporate entrepreneurship, an interesting question is whether the innovator is a leader, more than a professional.

Table 1. Schools of thought on entrepreneurship (Cunningham and Lischeron, 1991)

\begin{tabular}{|c|c|c|c|c|}
\hline $\begin{array}{l}\text { Entrepreneurial } \\
\text { Model }\end{array}$ & Central focus or purpose & Assumption & $\begin{array}{l}\text { Behaviours } \\
\text { skills }\end{array}$ & Situation \\
\hline $\begin{array}{l}\text { "Great } \\
\text { School }\end{array}$ & $\begin{array}{l}\text { The entrepreneur has an intuitive } \\
\text { ability - a sixth sense - and traits and } \\
\text { instincts he/ she is born with }\end{array}$ & $\begin{array}{l}\text { Without this "inborn" intuition, } \\
\text { the individual would be like the } \\
\text { rest of us mortals who "lack what } \\
\text { it takes" }\end{array}$ & $\begin{array}{l}\text { Intuition, vigor, } \\
\text { energy, persistence, } \\
\text { and self-esteem }\end{array}$ & Start-up \\
\hline $\begin{array}{l}\text { Psychological } \\
\text { Characteristics } \\
\text { School }\end{array}$ & $\begin{array}{l}\text { Entrepreneurs have unique values, } \\
\text { attitudes, and needs which drive them }\end{array}$ & $\begin{array}{l}\text { People behave in accordance with } \\
\text { their values; behaviour results } \\
\text { from attempts to satisfy needs }\end{array}$ & $\begin{array}{l}\text { Personal values, risk } \\
\text { taking, need for } \\
\text { achievement, and } \\
\text { others }\end{array}$ & Sta \\
\hline Classical School & $\begin{array}{l}\text { The central characteristic of } \\
\text { entreprenerial } \\
\text { innovation }\end{array}$ & $\begin{array}{l}\text { The critical aspect of } \\
\text { entrepreneurship is in the process } \\
\text { of doing rather than owning }\end{array}$ & $\begin{array}{l}\text { Innovation, } \\
\text { creativity, } \\
\text { discovery }\end{array}$ & $\begin{array}{l}\text { Start-up and } \\
\text { early } \\
\text { growth }\end{array}$ \\
\hline $\begin{array}{l}\text { Management } \\
\text { School }\end{array}$ & $\begin{array}{l}\text { Entrepreneurs are organizers of } \\
\text { economic ventures; they are people } \\
\text { who organize, own, manage, and } \\
\text { assume risk }\end{array}$ & $\begin{array}{l}\text { Entrepreneurs can be developed } \\
\text { or trained in the technical } \\
\text { functions of management }\end{array}$ & $\begin{array}{l}\text { Production planning, } \\
\text { people organizing, } \\
\text { capitalization, and } \\
\text { budgeting }\end{array}$ & $\begin{array}{l}\text { Early } \\
\text { growth and } \\
\text { maturity }\end{array}$ \\
\hline Leadership School & $\begin{array}{l}\text { Entrepreneurs are leaders of people; } \\
\text { they have the ability to adapt their } \\
\text { style to the needs of people }\end{array}$ & $\begin{array}{l}\text { An entrepreneur cannot } \\
\text { accomplish his/ her goals alone, } \\
\text { but depends on others }\end{array}$ & $\begin{array}{l}\text { Motivating, directing, } \\
\text { and leading }\end{array}$ & $\begin{array}{l}\text { Early } \\
\text { growth and } \\
\text { maturity }\end{array}$ \\
\hline $\begin{array}{l}\text { Intrapreneurship } \\
\text { School }\end{array}$ & $\begin{array}{l}\text { Entrepreneurial skills can be useful in } \\
\text { complex organizations; } \\
\text { intrapreneurship is the development } \\
\text { of independent units to create, } \\
\text { market, and expand services }\end{array}$ & $\begin{array}{l}\text { Organizations need to adapt to } \\
\text { survive; entrepreneurial activity } \\
\text { leads to organizational building } \\
\text { and entrepreneurs become } \\
\text { managers }\end{array}$ & $\begin{array}{l}\text { Alertness to } \\
\text { opportunities, } \\
\text { maximizing decisions }\end{array}$ & $\begin{array}{l}\text { Maturity } \\
\text { and change }\end{array}$ \\
\hline
\end{tabular}

Following discource analysis and its method, a number of fundamental premises and paradigms of entrepreneurship can be suggested from the above. Key aspects would include i) the treatment of risk and reward, ii) assignment, iii) responsibility, and iv) evaluation. By implication, it is difficult to remove uncertainty and risk from entrepreneurship. Yet, there may be different ways to overcome risk and share rewards, and the current, dominant method may not be the best. To a great extent, entrepreneurship is modelled as individualistic in nature. Entrepreneurs mostly compete and struggle to make it to the top, and are only then recognized and rewarded - competition may be seen as a viable method to identify entrepreneurs. Failure during venturing can be fatal for the entrepreneur. The development of the entrepreneur and worth of the entrepreneur even after failure receives less attention. The responsibility of risk bearing may lie mostly with the entrepreneur. Entrepreneurs generally venture on their own, and mainly (need to) take first initiative - rather than being assigned, they (need to) volunteer themselves. Related to the above, the entrepreneur is depicted as an owner, rather than a representative - to a large extent, entrepreneurs can be contrasted - rather than compared - with earlier century settlers, colonists, and pioneers, ordained by sovereigns. Profit is seen as a dominant evaluation criterion, and may already be referenced in the infancy of the opportunity or venture. Even though it may be a necessary criterion, it may not necessarily permit a holistic evaluation. 
Table 2 list the schools of strategy of Mintzberg et al (1998). It is clear that a number of these schools are also represented in entrepreneurship literature. Applying this to entrepreneurship, the view is that the concepts and areas of learning, power, environment and configuration can receive further attention, particulalry when viewing entrepreneurs as a resource that must be optimized.

Table 2. The strategy schools (Mintzberg et al, 1998)

\begin{tabular}{|c|c|}
\hline \\
\hline School & Perspective \\
\hline Design School & Strategy formation as a process of conception \\
\hline Planning School & Strategy formation as a formal process \\
\hline Positioning School & Strategy formation as an analytical process \\
\hline Entrepreneurial School & Strategy formation as a visionary process \\
\hline Cognitive School & Strategy formation as a mental process \\
\hline Learning School & Strategy formation as an emergent process \\
\hline Power School & Strategy formation as a process of negotiation \\
\hline Cultural School & Strategy formation as a collective process \\
\hline Environmental School & Strategy formation as a reactive process \\
\hline Configuration School & Strategy formation as a process of transformation \\
\hline
\end{tabular}

\subsection{Entrepreneurs as Resource}

Below, venture valuation (as reflection on venture creation), opportunity, social entrepreneurship, leadership, and the characterestics of entrepreneurs are briefly discussed. The objective is to describe the role or function of the entrepreneur.

\subsubsection{Venture Creation}

Venture valuation is briefly reviewed, as a reflection on venture creation. Figure 1 shows the variables of the conceptual framework of new venture creation of Gartner (1985). Table 3 and 4 list the venture evaluation criteria delineated by Tyebjee \& Bruno (1984), and MacMillan et al (1985), respectively. The figure and tables should make it clear what is built into the eventual venture of the entrepreneur, should he succeed, and thus also mirrors the form of output provided by the entrepreneur. The entrepreneur is then also a builder, given that he starts with less than an idea, and upon success, ends with a venture as organization. From this it is also clear that the entrepreneur draws upon knowledge and experience. 


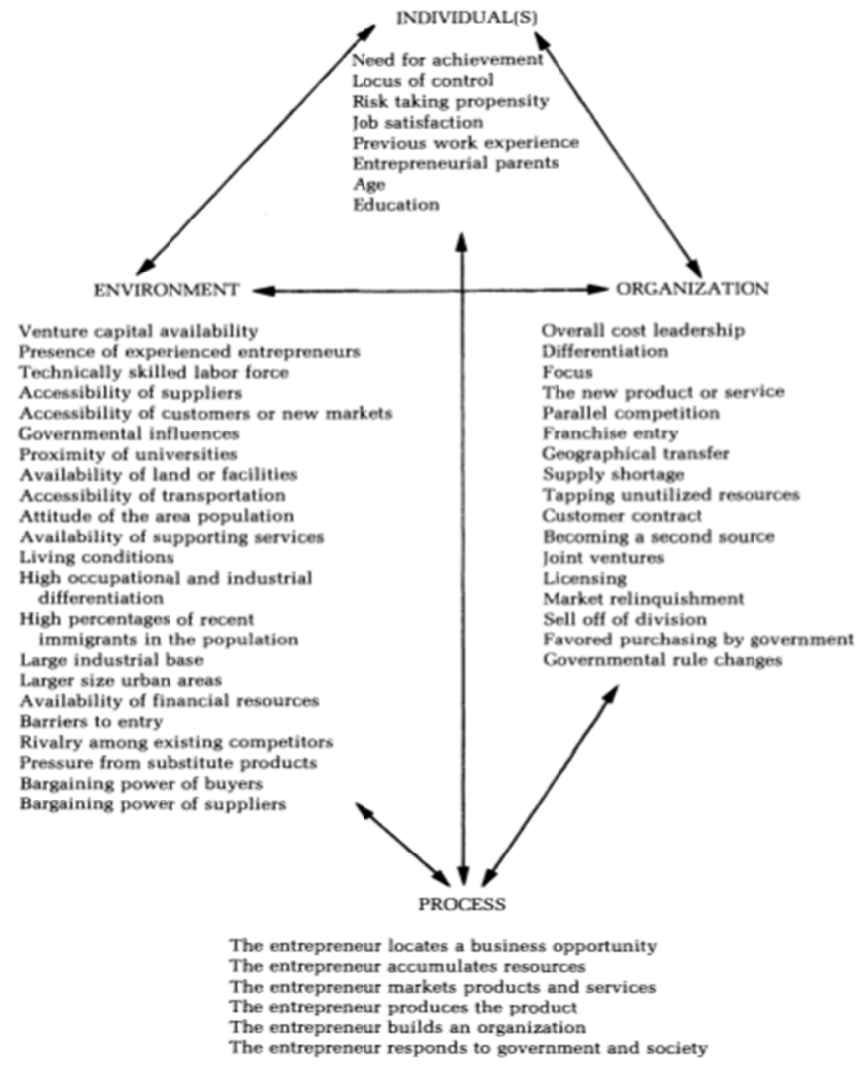

Figure 1. Variables in new venture creation (Gartner, 1985)

Table 3. Venture Evaluation Criteria (Tyebjee \& Bruno, 1984)

\begin{tabular}{|c|c|c|c|c|c|}
\hline \multicolumn{2}{|c|}{$\begin{array}{l}\text { Wells (1974) } \\
\text { Sample: Eight Venture Capital Firms } \\
\text { (Personally interviewed) }\end{array}$} & \multicolumn{2}{|l|}{$\begin{array}{l}\text { Poindexter (1976) } \\
\text { Sample: } 97 \text { Venture Capital Firms } \\
\text { (Mailed questionaires) }\end{array}$} & \multicolumn{2}{|c|}{$\begin{array}{l}\text { Tyebjee \& Bruno (study I) } \\
\text { Sample: } 46 \text { Venture Capitalists } \\
\text { (Telephone survey, open-ended questions) }\end{array}$} \\
\hline Factor & $\begin{array}{l}\text { Average } \\
\text { Weight }\end{array}$ & $\begin{array}{l}\text { Investment Criteria by Rank Order } \\
\text { of Importance }\end{array}$ & Rank & Factor & $\begin{array}{l}\% \text { of Respondents } \\
\text { Mentioning }\end{array}$ \\
\hline $\begin{array}{l}\text { Management } \\
\text { Commitment }\end{array}$ & 10.0 & Quality of Management & 1 & $\begin{array}{l}\text { Management Skills \& } \\
\text { History }\end{array}$ & 89 \\
\hline Product & 8.8 & Expected Rate of Return & 2 & Market Size/ Growth & 50 \\
\hline Market & 8.3 & Expected Risk & 3 & Rate of Return & 46 \\
\hline Marketing Skill & 8.2 & Percentage Equity Share of Venture & 4 & Market Niche/ Position & 20 \\
\hline Engineering Skill & 7.4 & Management Stake in Firm & 5 & Financial History & 11 \\
\hline Marketing Plan & 7.2 & $\begin{array}{l}\text { Financial Provisions for Investor } \\
\text { Rights }\end{array}$ & 6 & Venture Location & 11 \\
\hline Financial Skill & 6.4 & Venture Development Stage & 7 & Growth Potential & 11 \\
\hline Manufacturing Skill & 6.2 & Restrictive Covenants & 8 & Barriers to Entry & 11 \\
\hline References & 5.9 & Interest or Dividend Rate & 9 & Size of Investment & 9 \\
\hline $\begin{array}{l}\text { Other Participants in } \\
\text { Deal }\end{array}$ & 5.0 & Present Capitalization & 10 & $\begin{array}{l}\text { Market/ } \\
\text { Expertise }\end{array}$ & 7 \\
\hline Industry/ Technology & 4.2 & Investor Control & 11 & Venture Stage & 4 \\
\hline Cash-Out Method & 2.3 & Tax Shelter Consideration & 12 & Stake of Entrepreneur & 4 \\
\hline
\end{tabular}


Table 4. The criteria used by venture capitalists when they evaluate venture proposals (MacMillan et al, 1985)

\begin{tabular}{|c|c|c|c|}
\hline & & Mean & $\mathrm{SD}$ \\
\hline I & The entrepreneur's personality & & \\
\hline 1 & Capable of sustained intense effort & 3.60 & 0.57 \\
\hline 2 & Able to evaluate and react to risk well & 3.34 & 0.73 \\
\hline 3 & Articulate in discussing venture & 3.11 & 0.71 \\
\hline 4 & Attends to detail & 2.82 & 0.69 \\
\hline 5 & Has a personality compatible with mine & 2.09 & 0.81 \\
\hline II & The entrepreneur's experience & & \\
\hline 6 & Thoroughly familiar with the market targeted by venture & 3.58 & 0.57 \\
\hline 7 & Demonstrated leadership ability in past & 3.41 & 0.67 \\
\hline 8 & Has a track record relevant to venture & 3.24 & 0.69 \\
\hline 9 & The entrepreneur was referred to me by a trustworthy source & 2.03 & 0.62 \\
\hline 10 & I am already familiar with the entrepreneur's reputation & 1.83 & 0.71 \\
\hline III & Characteristics of the product or service & & \\
\hline 11 & The product is proprietary or can be otherwise protected & 3.11 & 0.71 \\
\hline 12 & The project enjoys demonstrated market acceptance & 2.45 & 0.74 \\
\hline 13 & The product has been developed to the point of a functioning prototype & 2.38 & 0.90 \\
\hline 14 & The product may be described as "high tech" & 2.03 & 0.96 \\
\hline IV & Characteristics of the market & & \\
\hline 15 & The target market enjoys a significant growth rate & 3.34 & 0.64 \\
\hline 16 & The venture will stimulate an existing market & 2.43 & 0.76 \\
\hline 17 & The venture is an industry with which I am familiar & 2.36 & 0.78 \\
\hline 18 & There is little threat of competition during the first three years & 2.33 & 0.72 \\
\hline 19 & The venture will create a new market & 1.82 & 0.83 \\
\hline $\mathbf{V}$ & Financial considerations & & \\
\hline 20 & I require a return equal to at least 10 times my investment within $5-10$ years & 3.42 & 0.79 \\
\hline 21 & I require an investment that can easily be made liquid (e.g. taken public or acquired) & 3.17 & 0.89 \\
\hline 22 & I require a return equal to at least 10 times my investment within at least 5 years & 2.34 & 0.81 \\
\hline 23 & I will not be expected to make subsequent investments & 1.34 & 0.52 \\
\hline 24 & I will not participate in latter rounds of investment (requires my participation in the initial round of investment) & 1.20 & 0.45 \\
\hline
\end{tabular}

\subsubsection{Opportunity}

Short et al (2010) note the different views on opportunity: a popular school of thought regarding opportunity is that opportunities are discovered. A popular contrasting school of thought is that opportunities are created. Others view opportunities as products of a creative process that is more gradual, involving a synthesis of ideas over time. Still other definitions focus on the chance to introduce innovative goods, services, or processes. Some of the antecedents of opportunity listed by Short et al (2010) are: experience, alertness, learning, timing, cognition, and heuristics.

Ardichvili et al (2003) define the concept of opportunity, opportunity development, opportunity evaluation, and opportunitiy recognition. An opportunity may be the chance to meet a market need (or interest or want) through a creative combination of resources to deliver superior value. Opportunities describe a range of phenomena that begin unformed and become more developed through time. Opportunity development refers to the fact that opportunities begin as simple concepts that become more elaborate as entrepreneurs develop them. Opportunity development is regarded as a continuous, proactive process. Opportunity evaluation pertain to the evaluation of opportunities at each stage of their development. Ardichvili et al (2003) state that, in entrepreneurship literature, opportunity recognition appears to include three distinct processes: (1) sensing or perceiving market needs and/ or underemployed resources, (2) 
recognizing or discovering a fit between particular market needs and specified resources, and (3) creating a new fit between heretofore separate needs and resources in the form of a business concept. These processes represent, respectively, perception, discovery, and creation.

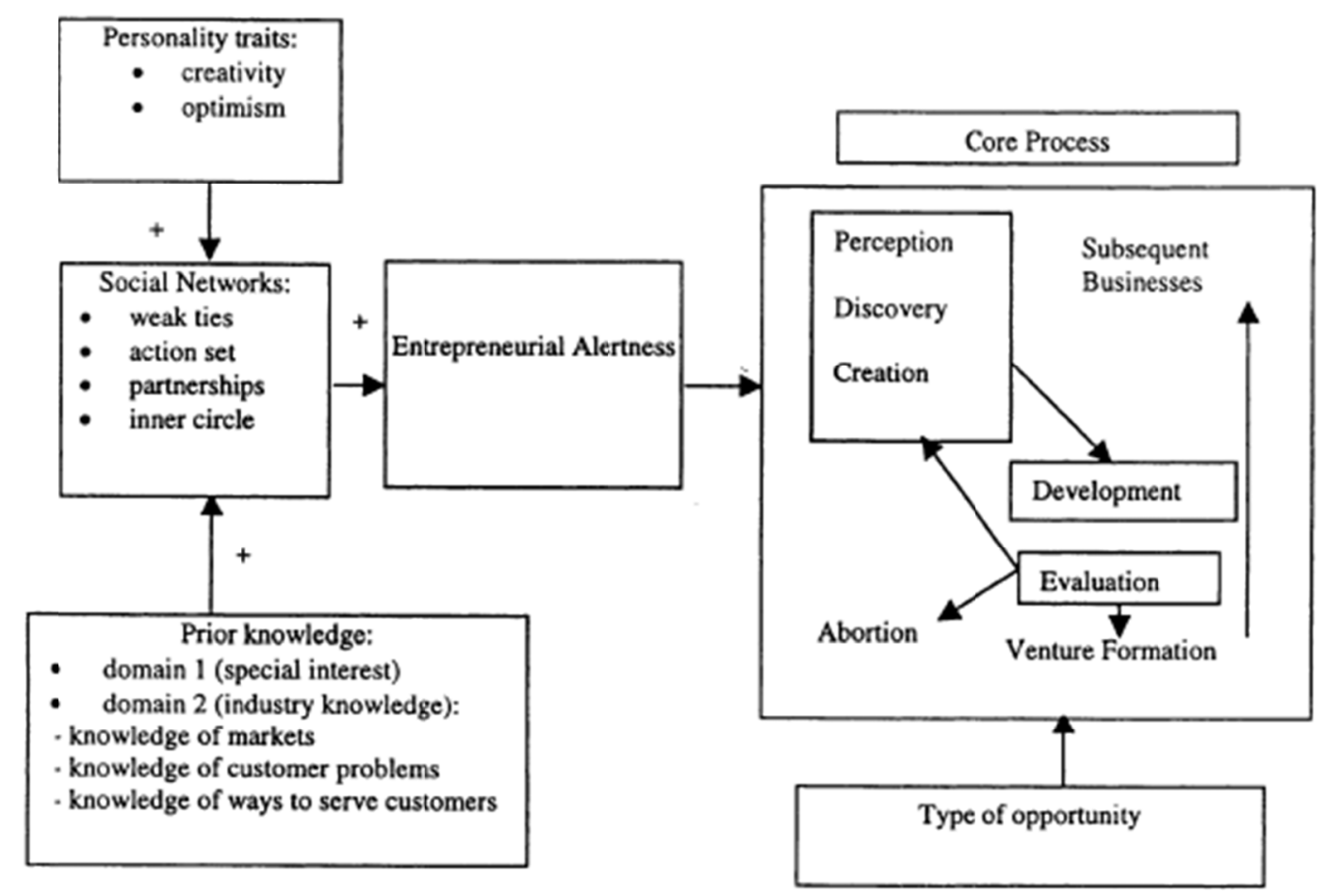

Figure 2. Opportunity identification and development model (Ardichvili et al, 2003)

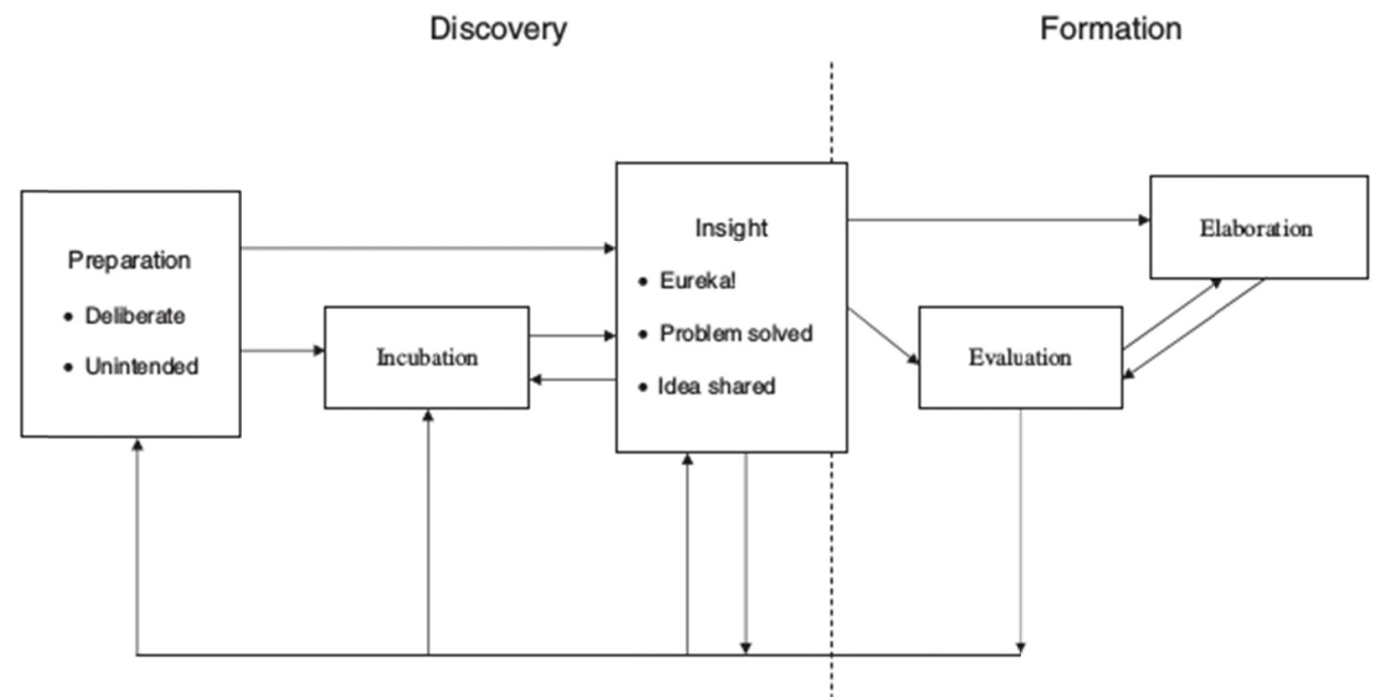

Figure 3. Creativity-Based Model of Opportunity Recognition (Corbett, 2005) 


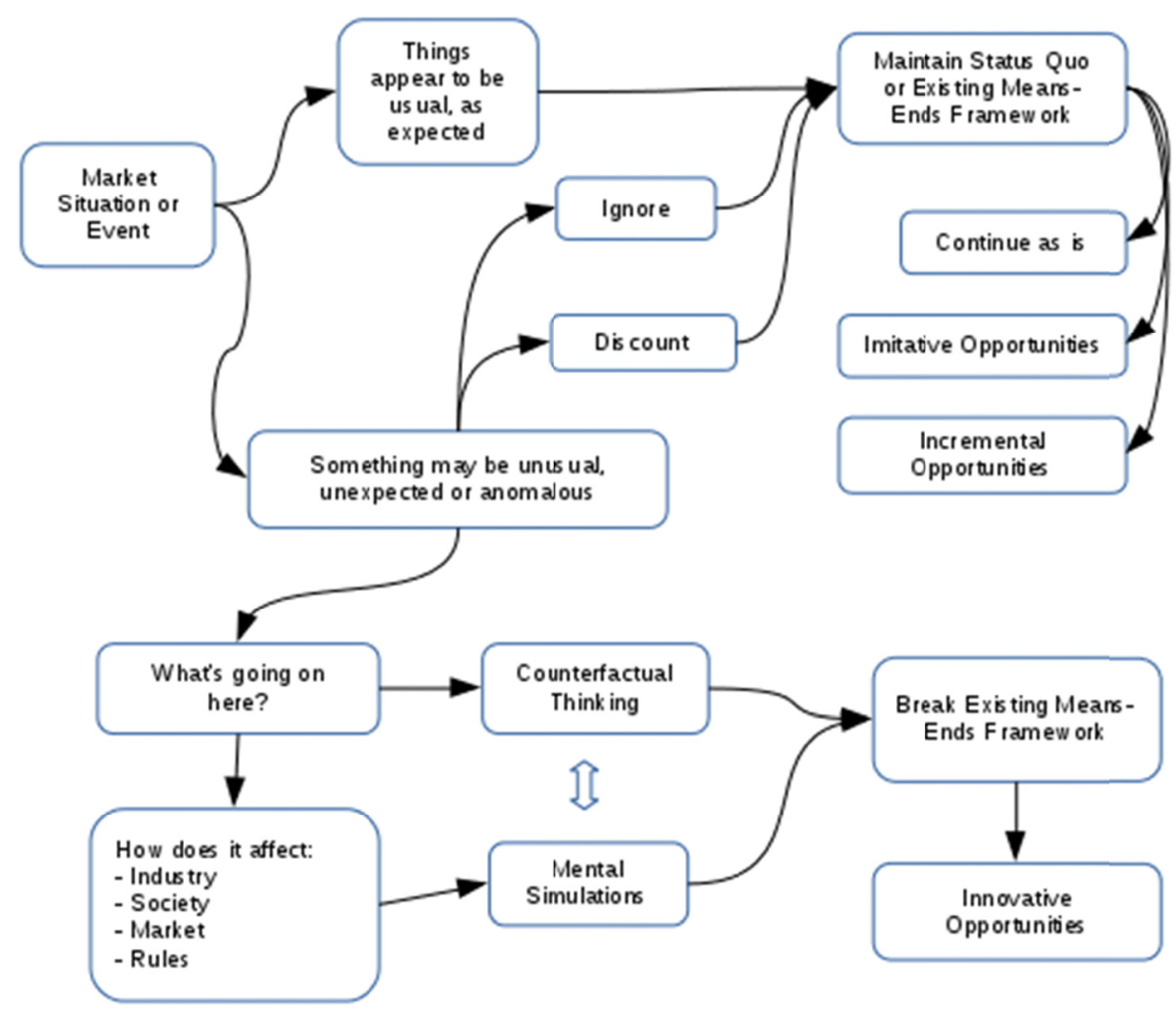

Figure 4. Alertness and the opportunity identification process (Gaglio and Katz, 2001)

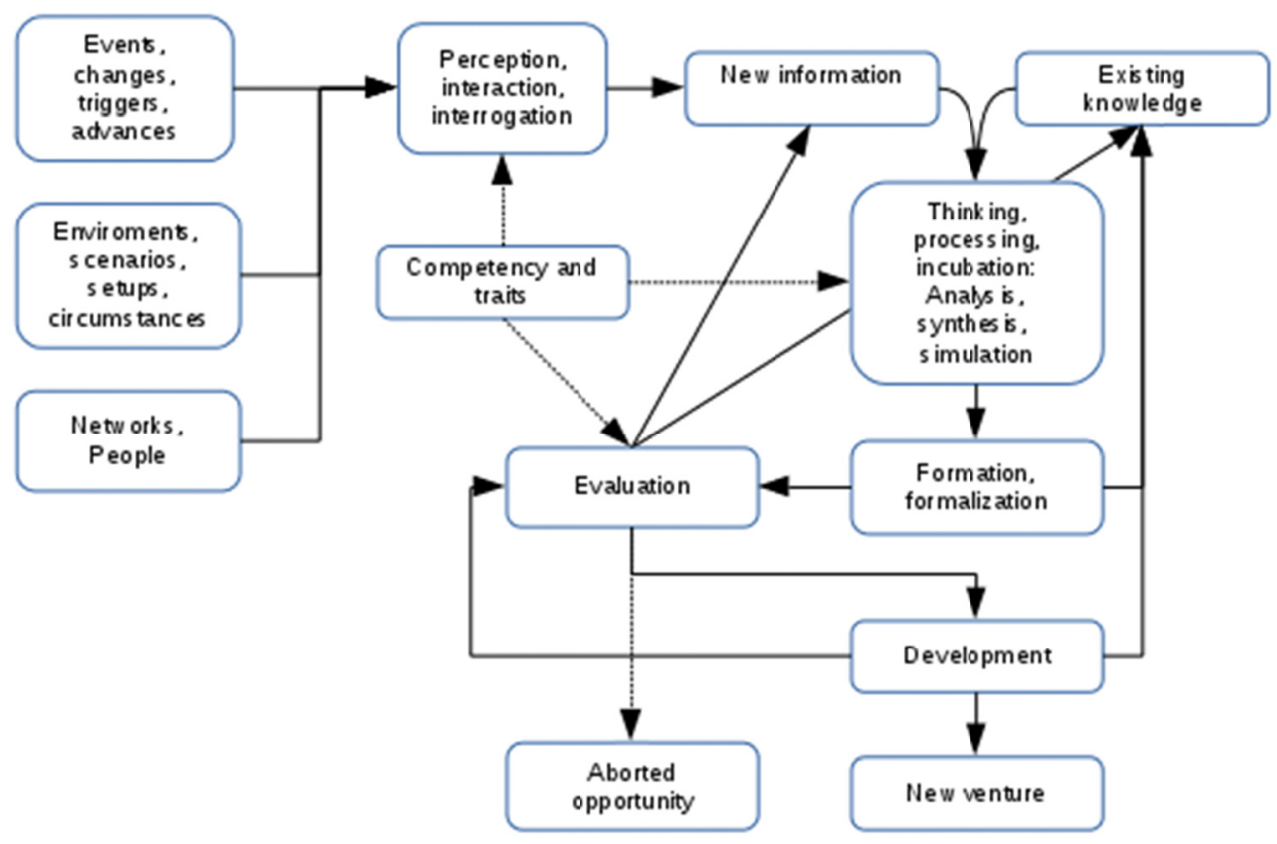

Figure 5. Opportunity recognition and development

Perception: Either kind of opportunity - market need or underemployed resources - may be identified or recognized by some individuals and not others. This is ascribed to the heterogeneity in individuals' sensitivity to opportunities for creation and delivery of new value. Discovery: Creation of a business concept that matches market needs with resources must logically follow perception of both the needs and the resources. But business concept creation is more than perception and discovery. Concept creation involves redirecting or recombining resources in order to create and deliver value superior to that currently available. Concept creation may go well beyond adjustment of current matches of 
resources and needs and may even lead to dramatic restructuring of an existing business or radical innovation.

Figure 3 and 4 show the creativity-based model of opportunity recognition of Corbett (2005), and the alertness and the opportunity identification process of Gaglio and Katz (2001). Figure 2, 3, and 4 stress the knowledge, alertness, cognitive abilities, and insight of the entrepreneur. Figure 5 attempts to combine these models, with greater emphasis on the activities of the entrepreneur. It is seen that the entrepreneur engages - perceive, interrogate, and interact with - his extended environment, discovers and formalizes opportunities, further develops opportunities, and evaluates them.

\subsubsection{Social Entrepreneurship}

According to Peredo and McLean (2006), there is broad agreement that social entrepreneurs and their undertakings are driven by social goals; that is, the desire to benefit society in some way. In other words, the social entrepreneur aims to increase social value in some way, i.e. to contribute to the welfare or well being in a given human community. Weerawardena and Mort (2006) see social value creation as influenced by innovativeness, proactiveness, and risk management, and bounded or constrained by sustainability, social mission, and environment.

In comparing the opportunity recognition process of commercial and social entrepreneurship, there do not seem to be a significant difference (Austin et al, 2006; Weerawardena and Mort, 2006). With social entrepreneurship, impacting or changing the status quo or environment seem to be a prominent theme.

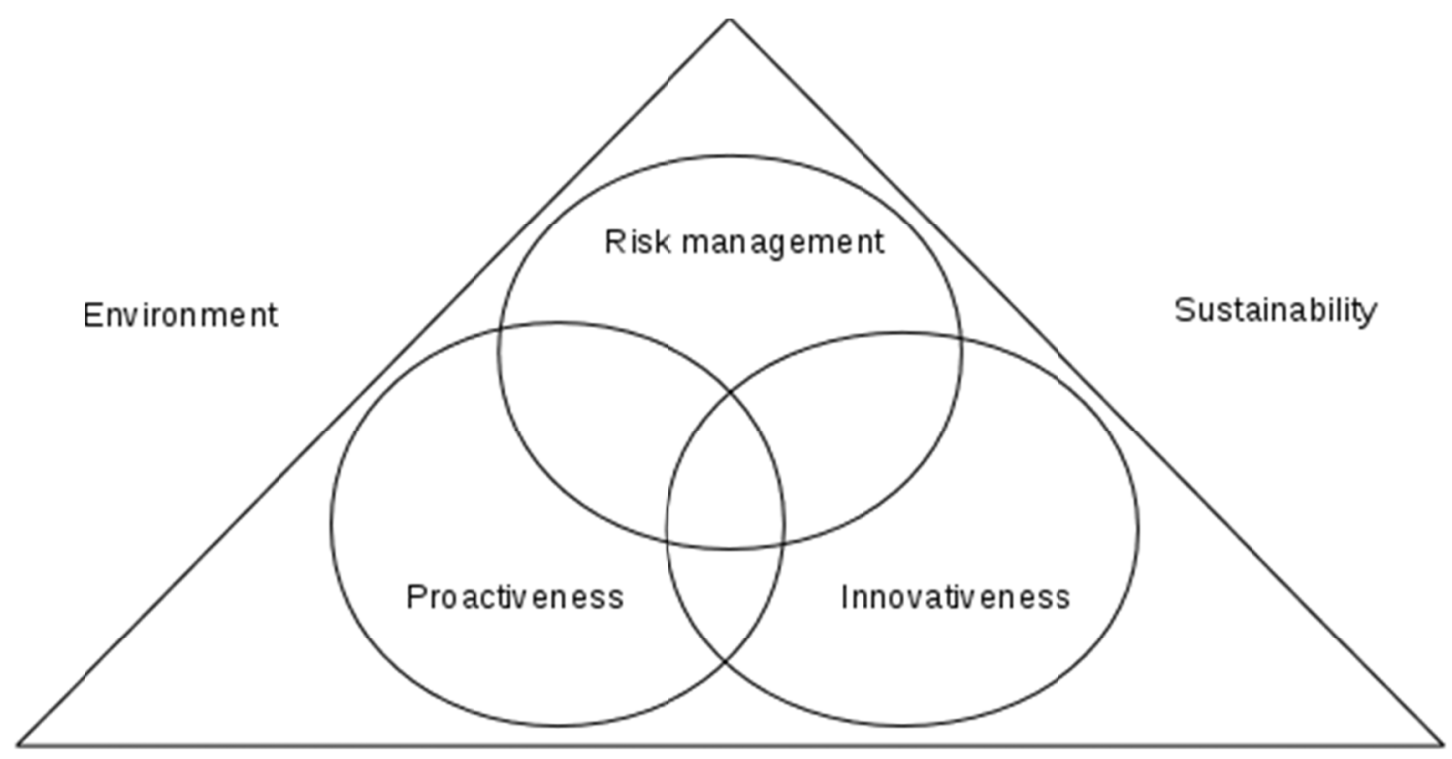

\section{Social mission}

Figure 6. Bounded multidimensional model of social entrepreneurship (Weerawardena and Mort, 2006)

\subsubsection{The Characteristics of Entrepreneurs}

Gartner (1985) delineates a number of entrepreneurial personalities: a "captain of industry"; a hard-headed risk bearer; a risk taker; a "rapacious risk avoider"; a person that merely metamorphoses into an entrepreneur at certain moments and is something else the rest of the time; a person with a need for achievement and/ or a capacity for innovation; a "displaced person"; something close to a juvenile delinquent; a "man-apart"; a person with an absolutely clear-headed (veridical) perception of reality; an aberrant "artist" with an "innate sense of impending change"; a completely political animal; a community builder.

According to Gartner (1985), some of the physcological characteristics of entrepreneurs are: need for achievement, locus of control, risk taking propensity, job satisfaction, previous work experience, entrepreneurial parents, age, and education. Chrisman et al (1998) provides an extensive list of the characteristics and attributes of entrepreneurs. Vecchio (2003) lists the "big five" of entrepreneurship as: a) risk-taking propensity, b) need for achievement, c) need for autonomy, d) self-efficacy, and e) locus of control. 
Table 5. Entrepreneurial Variables Affecting New Venture Performance (adapted from Chrisman et al, 1998)

\begin{tabular}{ll}
$\begin{array}{l}\text { Personality } \\
\text { Characteristics }\end{array}$ & $\begin{array}{l}\text { Autonomy; Confidence; Initiative; Locus of control; Need for achievement; Need for affiliation; Need for } \\
\text { power; Personality type; Risk-taking propensity; Self-reliance; Tolerance for ambiguity }\end{array}$ \\
\hline $\begin{array}{ll}\text { Values and Beliefs } \\
\text { Skills }\end{array}$ & $\begin{array}{l}\text { Contribution to society; Power; Security; Status; Wealth } \\
\text { Communication skills; Financial skills; Interpersonal skills; Managerial skills; Manufacturing skills; Marketing } \\
\text { skills; Organizational skills; Personnel skills; Technical skills }\end{array}$ \\
$\begin{array}{l}\text { Experience } \\
\begin{array}{l}\text { Education } \\
\text { and }\end{array}\end{array}$ & $\begin{array}{l}\text { Age; Entrepreneurial parents; Experience in founding companies; Experience in high-growth organizations; } \\
\text { Experience in large firm; Experience in similar positions; Formal education; General management experience; }\end{array}$ \\
& Industry experience; Pre-startup training; Shared experience of founders; Startup experience
\end{tabular}

\subsubsection{Entrepreneurship and Leadership}

Cogliser and Brigham (2004) examine the intersection between the fields of leadership and entrepreneurship, with an emphasis on how the path taken by leadership research can inform entrepreneurship. They note that Schumpeter (1934) distinguished managers from entrepreneurs where managers control, guarantee discipline, and introduce order. His view was that entrepreneurship was a special case of leadership (social leadership) and was distinguished from other forms of leadership in terms of one who created a company rather than managing an existing one (Schumpeter, 1934). While the content of the comparisons are not the same, the contrast between managers and entrepreneurs is similar in form to the distinction others have made between managers and leaders.

Even though there is a distinction between leaders and leadership (Cogliser and Brigham, 2004), one may perhaps consider the position that an entrepreneur is neither a manager, nor a leader per se, but rather a professional. In the field of innovation, the innovator is not predominantly and principally depicted as a leader, and may merely be a professional. From studies of corporate entrepreneurship, such as Cohen (2002) and Eyal and Kark (2004), it is deduced that correct leadership allows specialization. In these contexts, the entrepreneur does not necessarily have to be the leader, but can simply be the professional. As innovation, entrepreneurship may be seen as more of a team activity, rather than an individual activity, with the entrepreneur merely a professional with certain expertise within the team.

Table 6. Leadership and entrepreneurship models across life cycles (adapted from Cogliser and Brigham, 2004)

\begin{tabular}{|c|c|c|}
\hline $\begin{array}{l}\text { Life cycle stage: introduction } \\
\text { and elaboration }\end{array}$ & $\begin{array}{lll}\begin{array}{l}\text { Selected } \\
\text { models }\end{array} & \text { relevant leadership } \\
\end{array}$ & Selected relevant entrepreneurship models \\
\hline What is a leader/ entrepreneur? & $\begin{array}{l}\text { Traits } \\
\text { Managerial motivation }\end{array}$ & $\begin{array}{l}\text { Locus of control; Need for achievement; Risk-taking } \\
\text { propensity; Tolerance for ambiguity; Risk avoidant behavior }\end{array}$ \\
\hline $\begin{array}{l}\text { What does the leader/ } \\
\text { entrepreneur do? }\end{array}$ & $\begin{array}{l}\text { Consideration/Initiating Structure } \\
\text { Task-oriented/relations-oriented } \\
\text { behavior } \\
\text { Managerial behavior }\end{array}$ & $\begin{array}{l}\text { Strategic adaptation } \\
\text { Venture creation behavior }\end{array}$ \\
\hline $\begin{array}{l}\text { In what context does the } \\
\text { leader/entrepreneur operate? }\end{array}$ & $\begin{array}{l}\text { Path-goal theory } \\
\text { Contingency theory } \\
\text { Normative decision model }\end{array}$ & $\begin{array}{l}\text { Rates Approach } \\
\text { Life cycle }\end{array}$ \\
\hline
\end{tabular}




\begin{tabular}{|c|c|c|}
\hline $\begin{array}{l}\text { Life cycle stage: evaluation/ } \\
\text { augmentation }\end{array}$ & Selected relevant leadership models & $\begin{array}{l}\text { Selected relevant entrepreneurship } \\
\text { models }\end{array}$ \\
\hline What is a leader/ entrepreneur? & $\begin{array}{l}\text { Charismatic leadership } \\
\text { Leader flexibility } \\
\text { Leadership motive pattern theory } \\
\text { Managerial competencies } \\
\text { Romance of leadership }\end{array}$ & $\begin{array}{l}\text { Cognitive approach } \\
\text { Psychological approach } \\
\text { Entrepreneurial motivation) } \\
\text { Individual differences }\end{array}$ \\
\hline What does the leader/ entrepreneur do? & $\begin{array}{l}\text { Influence tactics } \\
\text { Transformational leadership } \\
\text { Vertical dyad linkage/leader-member } \\
\text { exchange }\end{array}$ & $\begin{array}{l}\text { Communication } \\
\text { Entrepreneurial alertness } \\
\text { Opportunity recognition } \\
\text { Risk-taking/risk management } \\
\text { Serial and portfolio entrepreneurs } \\
\text { Vision articulation }\end{array}$ \\
\hline $\begin{array}{l}\text { In what context does the } \\
\text { leader/entrepreneur operate? }\end{array}$ & $\begin{array}{l}\text { Implicit leadership theory/ leadership } \\
\text { information processing } \\
\text { Leader/ member attribution } \\
\text { Strategic leadership } \\
\text { Visionary leadership }\end{array}$ & $\begin{array}{l}\text { Corporate entrepreneurship } \\
\text { Cross-cultural entrepreneurship } \\
\text { General environment } \\
\text { Family business }\end{array}$ \\
\hline
\end{tabular}

\begin{tabular}{|c|c|c|c|}
\hline $\begin{array}{l}\text { Life cycle stage: consolidation/ } \\
\text { accommodation }\end{array}$ & Selected relevant leadership models & $\begin{array}{l}\text { Selected relevant } \\
\text { models }\end{array}$ & entrepreneurship \\
\hline What is a leader/ entrepreneur? & $\begin{array}{l}\text { Cognitive, social, and emotional } \\
\text { intelligence } \\
\text { Managerial intelligence } \\
\text { Narcissistic leadership } \\
\text { Personality } \\
\text { Traits, skills, and competencies }\end{array}$ & (Emerging) & \\
\hline What does the leader/ entrepreneur do? & $\begin{array}{l}\text { Authentic leadership } \\
\text { Dysfunctional leadership } \\
\text { Empowerment } \\
\text { Ethical leadership } \\
\text { Relational leadership } \\
\text { Shared leadership } \\
\text { Visionary leadership }\end{array}$ & Nascent entrepreneurs & \\
\hline $\begin{array}{l}\text { In what context does the leader/entrepreneur } \\
\text { operate? }\end{array}$ & $\begin{array}{l}\text { Complexity } \\
\text { E-leadership } \\
\text { Leading creative people } \\
\text { Leading across cultures }\end{array}$ & (Emerging) & \\
\hline
\end{tabular}

\subsubsection{The Role of the Entrepreneur}

From the above sections, it is clear that:

(1) Entrepreneurs employ skills, knowledge, and conception (Ardichvili et al, 2003; Corbett, 2005; Gaglio and Katz, 2001; Chrisman et al, 1998).

(1) Entrepreneurs interpret environments differently (Palich and Bagby, 1995), and have a specific function or output in terms of entrepreneurship and innovation.

(1) To do so, they access or generate, and then transform specific information regarding existing and potential products, markets, and competition. As part of opportunity recognition, entrepreneurs develop and work towards formal business opportunities as projects - concepts, plans, and solutions. The formal business opportunity carry a certain degree of risk, that is only resolvable with time, as more information becomes available (Ardichvili et al, 2003; Shepherd, 1999; Das and Teng, 1997; Dickson and Giglierano, 1986).

(1) Entrepreneurs pursue ventures as projects. The project may be seen through, or prematurely terminated, as its uncertainty resolves, and its feasibilty crystalizes. Projects may succeed or fail. This may or may not make or break the entrepreneur, depending on his position (Dickson and Giglierano, 1986).

(1) Certain people may have a personality and character that is prone to and suitable for entrepreneurship, and that might be difficult to teach. However, employed as an entrepreneur, such an apt person can further develop with time: natural entrepreneurs can be further developed as resource.

(1) Entrepreneurs may be at different levels of self-actualization: development, personal wealth, experience, 
achievement, and independence, and may thus have different preferences or expectations in terms of risk or security, freedom, autonomy, satisfaction or expression, and so forth (Chrisman et al, 1998; Gartner, 1985).

(1) Different variants of entrepreneurs may exist, and may be employed in different capacities and for different reasons or outcomes (Gartner, 1985; Peredo and McLean 2006). In addition to benefiting themselves, entrepreneurs may be channeled to benefit organizations (intrapreneurship or corporate entrepreneurship) or societies (as social entrepreneurs), by improving social, economic or corporate conditions. Entrepreneurs may employ themselves, or may be employed by organizations, non-profits, and governments. Their profile would determine their best application.

This brings to the front a number of propositions regarding entrepreneurs:

Reliability: An entrepreneur can repeatedly innovate. Nicolaou and Birley (2003) seem to support this view.

Universality: When moved from one environment, context, or industry to another, given a reasonable amount of time and the necessary resources, the entrepreneur will again be able to innovate.

Potential and development: Entrepreneurs develop further with time.

Qualification: The entrepreneur may require a minimum level of education - whether informal or formal - as well as a minimum degree of experience, in business and industry.

Specialization: There is a specific role and function that the entrepreneur is best at. However, it may not necessarily pertain to the entire process of venture creation, from start to finish. Thus, with some aspects of venture creation, the entrepreneur should hardly be involved with. It may be that the entrepreneur specializes in opportunity recognition or venture creation. Or, it may be that, in order to achieve goals, the entrepreneur is not adverse to uncertainty, change, and do not shun away from learning.

Managability: As professionals, entrepreneurs can be managed as any other human resource, albeit along differerent ways - general principles of human resource management equally apply to entrepreneurs. Proper management can also increase the efficiency of the entrepreneur. Morris and Jones (1993), Lado and Wilson (1994), and Hayton (2005) support both points.

Efficiency: The entrepreneur can be made more efficient in his work. One potential way to do so would be by employing systems and processes. It is unlikely that all of the entrepreneur's routines are random, and may thus be standardized or optimized. Other types of support systems and processes may also aid the entrepreneur. Proper management may also improve the efficiency of entrepreneurs. A distinction is made between general management systems - systems that improve the management of the venture - and innovation-specific systems - systems that improve venturing tasks such as opportunity recognition and development. Barrett and Mayson (2007) demonstrate how management systems benefit entrepreneurs.

Authority and sphere of influence: The entrepreneur does not necessarily have to be the leader of the venture.

\subsection{The Organization of Entrepreneurs}

Below, networks, organizations, and corporations are considered as alternatives to a purely independent entrepreneurial venture. Corporations are crudely contrasted with organizations based on the extent of venturing - the extent by which entrepreneurship forms the predominant corporate strategy. In other words, here a corporation is seen as a more aggressive venturer than an organization, in scope and/ or scale.

\subsubsection{Networks}

Nicolaou and Birley (2003) argue that networks offer entrepreneurs four substantive benefits: they augment the opportunity identification process, provide access to a loci of resources, engender timing advantages, and constitute a source of status and referrals. In discussing alliances and networks in the context of entrepreneurship, Tracey and Clark (2003) list the potential benefits of networks as: i) better access to information, knowledge, skills and experience; ii) improved linkages and cooperation between network members, particularly between users and suppliers; iii) improved response capacity; iv) reduced risk, moral hazards, information and transaction costs; and v) improved trust and social cohesion. It is noted that in a network, the relationship among participants are mostly peer-to-peer, or equal-footing.

\subsubsection{Internal Corporate Venturing}

Organizations share a number of benefits with networks. Most, if not all of the benefits of networks, listed by Nicolaou and Birley (2003), and Tracey and Clark (2003), can be found in organizations as well. Given their organizational context, intrapreneurs may have a number of advantages and disadvantages relative to entrepreneurs:

Reputation: Organizations are better at building and conveying reputation or brand. This can signal trust, competence, knowledge, experience, capacity, recoursefulness, and familiarity to investors and customers. Even though they approach investors differently for funding, organizations are likely more reputable than entrepreneurs, in that they 
mirror the corporate reputation and brand, not their own. In general, reputation should reduce the cost of doing business. Shepherd (1999) argues that new ventures often need to establish a market presence and the legitimacy that comes with it - they must create a frame of reference with customers, and customers must be convinced that the product benefits outweigh the risks associated with its newness. However, it can be difficult and costly (in terms of both human and financial resources) for the new venture to construct such a customer frame of reference and market legitimacy.

Funding: Because they maintain product portfolios, organizations are able to sustain more constant revenue streams, and to build a more balanced risk structure. Furthermore, the assets of organizations are more liquid. Clearly, these factors are of importance to venture capatalists (Tyebjee \& Bruno, 1984; and MacMillan et al, 1985). This should allow organizations to access financial resources more cheaply than entrepreneurs. As is subsequently explained, this is seen as attributable to the structuring of risk, rather than the extent of risk undertaken.

Risk and reward: Pycraft et al (2004: 574) classify projects in terms of project objectives and project scope. This can be seen to relate to complexity, uncertainty, and duration (time). Mullins and Forlani (2005) argue that, when it comes to new venture decision making, the likelihood of loss (sinking or missing the boat) and the magnitude of loss (the size of the boat sunk or missed) capture the essence of entrepreneurial risk. The likelihood of loss entails either the potential to act too quickly on an unsubstantiated opportunity, thus "sinking the boat," or the potential to wait too long before acting, thus "missing the boat." Sinking the boat is defined as the likelihood that a new venture will fail to reach satisfactory sales; missing the boat is defined as as the likelihood that a very attractive opportunity will be overlooked, dismissed, or lost because of competitor preemption or changing markets. Huntsman and Hoban (1980) show that an attractive rate of return can be generated over time by well-diversified venture portfolios, but that it is conditional on the method and extent of diversification.

Even though Gartner (1985) rejects the CAPM (capital asset pricing model) model applied to SBUs (strategic business unit) of corporations, it is noted that there should be sufficient and significant difference between a portfolio of individual ventures, and a corporation holding and managing a portfolio of ventures as SBUs. Even if the corporation only holds ventures, and no established businesses, it should still have lower borrowing cost, compared to any of the individual ventures. Firstly, because of liquidity - if it trades publicly and the ventures do not. Secondly, its risk structure and cash flows may differ, particularly if the corporation is reputable to specialize in (management of) entrepreneurship, and particularly if the corporation holds a portfolio of ventures in different stages of maturity. There is also room for synergy and cooperation across the SBUs - on the other hand, Gartner (1985) is doubtful whether management can always add value to the SBUs.

Thus, it is questioned whether organizations engage in less risky ventures, compared to entrepreneurs. On the other hand, organizations amalgamate - rather than isolate - products and ventures, such that they possess a portfolio of products or ventures at different stages of their lifecycle. Organizations better balance or spread risk, and thus have greater risk capacity, allowing them to absorb more risk. With organizations, venture failure is not necessarily fatal. Their product portfolios balance existing products versus new products, and thus maturity, uncertainty, and extent.

A fundamental premise of entrepreneurship is the appropriate sharing of risk and reward between the core participants the entrepreneur and investor. In essence, it is also becomes an issue of valuing the knowledge capital the entrepreneur sources. In general, organizations only value knowledge capital in the case of success. The organization helps with the operational costs as part of opportunity development, and sources the assets required during this time. The intrapreneur receives a salary during venture development. The potential venture and the assets thereof essentially belongs to the corporation. Upon failure, the organization recovers the assets. Upon success, the intrapreneur is further rewarded possibly in the form of shares in the organization. Organizations are therefore in a better position to reduce and mitigate the cost associated with venture uncertainty and failure, which is given.

Resources: As part of an organization, intrapreneurs can easily manage, control and concentrate resource allocation, particularly during vital stages of venture creation. They should be in a better position to avoid termination of new ventures during a critical stage or decision.

Organizations are more prone to resource management and development, particularly systems and human resources (Hayton, 2005; Wright and McMahan, 1992) Intrapreneurs may benefit from more extensive organizational resources, particularly in the form of knowledge, leadership, training, and coaching. Organizations are also more prone to develop, and extract benefit out of systems that optimize processes and routines, and can afford such (Hidalgo and Albors, 2008; Liao and $\mathrm{Wu}, 2010)$. Some entrepreneurs may view such an approach to entrepreneurship or innovation as restrictive.

Organizations also reinvest resources, particularly knowledge and experience. Organizations can also more easily retain and expand compentencies - including entrepreneurship as competency - as well as management and leadership (Barrett and Mayson, 2007). 
Opportunity recognition and evaluation: Herbst and Barnard (2016) emphasize the process of innovation, and point out the role of management, operations and marketing as part of innovation. Evidently, opportunity development and opportunity evaluation require skill and input from a broad spectrum. Organizations should hypothetically be better positioned and more systematic, structural and objective in opportunity identification, development and evaluation. More extensive management, leadership, resources, information and knowledge are available to organizations.

Within organizations, intrapreneurs are more effectively distanced from the venture or project, allowing greater objectivity and also security. Intrapreneurs have greater freedom to, after evaluation, discard opportunities and pursue others, due to organizational support - failure can be managed, and made less severe (Stevenson and Jarillo, 2007). Intrapreneurs may be confined to the markets of the organization, depending on the strategic objectives of the firm (Sharma and Chrisman, 2007).

Organizations may be more susceptible to power plays, and may suffer from corporate inertia. In organizations, innovative culture is likely not given and must be actively built (Ireland et al, 2009; Stevenson and Jarillo, 2007; Barringer and Bluedorn, 1999). Viable ventures that are otherwise perfect, may easily be disregarded or overlooked this way. Consequently, intrapreneurs may experience less freedom in opportunity identification and selection.

Entrepreneurs are more dependent on investors, like venture capitalists. Investors essentially become a prominent participant and decision-maker during opportunity identification and evaluation, and may introduce their own criteria. Organizations may have the advantage of greater autonomy - not having to directly or initially sell their new ventures to investors, with greater freedom to develop the opportunities first.

Security: Within an organization, the entrepreneur self assumes less risk.

\subsubsection{Corporations}

Lewis et al (1999: 211) state that a corporation consists of a series of businesses, and as such corporate strategy must add value to the combined businesses, over and above the value of the individual businesses themselves. If this does not occur, there is no reason for combining the businesses - they would function just as well as separate, independent entities. Goold and Campbell (1991) argue that the corporation must: i) create value in each business unit, ii) create more value than the cost of the corporate overhead, and iii) create more value than would be created by another corporate owner of the business. Corporate entrepreneurship is proven, and it is clear that entrepreneurship can be utilized as a viable corporate strategy (Rice et al, 2000). Entrepreneurship is seen as the basis of the synergy or competitive advantage of the corporation as amalgamation of individual organizations, and how the corporation manages to add value - to create a sum greater than its parts.

Sharma and Chrisman (2007) differentiate between independent entrepreneurship and corporate entrepreneurship or corporate venturing. Corporate venturing is further classified as internal or external corporate venturing. Internal corporate venturing refers to the corporate venturing activities that result in the creation of organizational entities that reside within an existing organizational domain. External corporate venturing refers to corporate venturing activities that result in the creation of semi-autonomous or autonomous organizational entities that reside outside the existing organizational domain. Internal venturing is further classified in terms of structural autonomy, degree of relatedness to existing business, degree of innovation, and nature of sponsorship.

For purposes of this paper, a classification based on the extent of venturing, the source of ventures, and the duration or maturity of venturing, is also considered. Here, a corporation is defined as a corporation that explicitly focuses on entrepreneurship as competitive advantage, and that therefore devoutly incorporates new ventures, consequently likely from external entrepreneurs as sources, with the aim of only holding ventures as long as they are not matured. In other words, the corporation builds on internal venturing, relatively strong embeddedness, formal sponsorship, with mild restriction to degree of relatedness to existing business, a balanced or portfolio view in terms of degree of innovation, and an extensive portfolio of ventures. The predominant focus is on adding value during the venturing stage, not necessarily after the venture has matured. The corporation will then also draw in entrepreneurs at the early stage of opportunity identification or development.

The benefits that a corporation may offer entrepreneurs are similar to that of organizations. In addition, corporations have the potential to diversify more. Entrepreneurs can thus be offered greater flexibility and freedom. The corporation may further yield economies of scale, scope and time. The corporation may also specialize more - it may cultivate leadership, and thus specialize in opportunity recognition, development, and evaluation, as well as prototyping, knowledge management, resource management, and entrepreneurial management.

Based on the extent of venturing, corporations may have greater risk than organizations, as more of its cash flows are subject to uncertain ventures. Corporations that specialize in entrepreneurship also naturally assume more risk than organizations, given increased uncertainty in their venture portfolio as product portfolio. The increased complexity may 
pose a challenge to the corporation. Naturally, the corporation would experience greater challenges in terms of overall management. Gartner (1985) argue that a diversified corporation may make it difficult to source a management team with such a broad industry experience.

\subsubsection{The Factors Valued by Entrepreneurs in Terms of Organization}

In considering avenues of venturing, entrepreneurs may evaluate their position in terms of security, autonomy, and flexibility, opportunity, and self-expression. Table 7 contrasts the factors the organization as entity would impact or pursue, regardless of the organization type, and the factors likely pursued by entrepreneurs. Table 8 reflects the perceived differences between the entrepreneurial organizations types. The table entries are mostly hypothetical; the subsequent analysis reflects on the accuracy of table 8.

Security: Entrepreneurs likely have different preferences in terms risk and reward. Lower levels of risk and cost of organizations and corporations, may permit more entrepreneurs to come forward with opportunities (Amit et al, 1995), and should result in opportunity diversification. Entrepreneurs may prefer different combinations of risk exposure and resultant reward (Das and Teng, 1997).

Autonomy: Entrepreneurs may or may not be willing to be subject to leadership, management or corporate culture, even if it is more flexible in nature, or even if it benefits the entrepreneur. Corporations and networks ought to be less restrictive than organizations with regards to opportunity development. Entrepreneurs may not prefer the method and process of entrepreneurship of organizations and corporations, particularly if it stresses systems and processes to improve efficiency.

Flexibility: Entrepreneurs may desire greater flexibilty in the opportunities they wish to pursue.

Opportunity: Entrepreneurs may favour the avenue that would provide the greatest opportunity in terms of their venture, or aspirations.

Self-expression: Entrepreneurs may be more subjective in critically evaluating their ventures, and may be more adamant to see their idea through.

Table 7. The factors of influence of entrepreneurs and organization

\begin{tabular}{lc}
\hline Organization & Entrepreneur \\
\hline Resourcefulness (efficient utility of resources) & Security \\
Efficiency/ Professionality (structure; order; specialization) & Autonomy \\
$\begin{array}{l}\text { Responsiveness (ability and power to appropriately act on and respond to opportunity; possessing necessary } \\
\text { resources to move opportunities to ventures) }\end{array}$ & Flexibility \\
Rewarding stakeholders (maintaining profit) & Opportunity \\
Sustainability (survival; stability; longevity) & Self-expression \\
\hline
\end{tabular}

Table 8. Perceived Differences in entrepreneurial organization types

\begin{tabular}{llll}
\hline Factor & Above-norm & Average & Below-norm \\
\hline Resourcefulness & O, C & $\mathrm{N}$ & $\mathrm{E}$ \\
Responsiveness & $\mathrm{O}, \mathrm{C}$ & $\mathrm{N}$ & $\mathrm{E}$ \\
Flexibility & $\mathrm{E}, \mathrm{N}, \mathrm{C}$ & $\mathrm{O}$ & \\
Efficiency & $\mathrm{O}, \mathrm{C}$ & $\mathrm{N}$ & $\mathrm{E}$ \\
Risk & $\mathrm{E}$ & $\mathrm{N}, \mathrm{C}$ & $\mathrm{O}$ \\
Reward & $\mathrm{E}, \mathrm{N}$ & & $\mathrm{O}, \mathrm{C}$ \\
Sustainability & $\mathrm{O}, \mathrm{N}$ & $\mathrm{C}$ & $\mathrm{E}$ \\
E = Entrepreneur; O & Organization; C $=$ Corporation; N = Network \\
\hline
\end{tabular}

\subsection{Concluding Remarks}

The entrepreneur as resource was examined. In doing so, venture creation, opportunity, social entrepreneurship, leadership and the characteristics of entrepreneurs were considered. The different forms of organization of entrepreneurs were also considered, contrasting the objectives of the organization, with that of the entrepreneur.

\section{Methodology}

The study further examines a number of propositions regarding entrepreneurs as resource, and their organization. Semi-structured interviews were conducted with entrepreneurs, and professionals close to entrepreneurships and the 
entrepreneurship community - like investors, consultants and scholars - from South Africa. The study was not restricted to entrepreneurs, but extended to entrepreneurship professionals, provided they possess sufficient experience, as they have the ability to reflect on entrepreneurs and entrepreneurship from a different, yet relevant, perspective and vantage point. The interviewees have been directly involved with entrepreneurship, with appropriate level of experience. Ten interviews were conducted. The interviewees were asked twenty-five questions, divided into two sections.

During the interviews, the following definitions were conveyed to the respondents:

(1) Network: a collaboration of innovation and entrepreneurship. It is taken that funding is provided, and some form of management assistance or coaching is provided.

(1) Organization: a for-profit organization that may or may not be well-difersified. Entrepreneurship is practiced internally in the organization. However it is not necessarily the predominant corporate strategy, and innovation is generally limited to fit with existing business.

(1) Corporation: a for-profit organization that employs entrepreneurship as corporate strategy. Entrepreneurship is mainly practiced internally in the corporation: entrepreneurs are predominantly sourced outside of the corporation, and their ventures may still be in early stage of development. The entrepreneurs are incorporated in the corporation and its practices. Similar to the case of an organization, funding and resources are provided, and the assets remain the property of the corporation. A broad focus is followed, such that fit with existing business is only mildly considered. A balanced portfolio of level of venture innovation is maintained. The predominant focus is on adding value during venturing stage, not necessarily after the venture has matured.

\section{Entrepreneurship as resource}

1.1 Do you think that, given the necessary resources, entrepreneurs will always be able to create economic products or ventures in the end? Can entrepreneurs repeatedly venture and innovate?

\begin{tabular}{llll}
\hline 1.2 & Should their current opportunity fail, can entrepreneurs easily identify new opportunities? & Reliability of entrepreneurs. \\
\hline 1.3 & $\begin{array}{l}\text { Are entrepreneurs bound by industry? If the entrepreneur is moved from one industry to } \\
\text { another, will the entrepreneur be able to venture again, given sufficient time and resources? }\end{array}$ & $\begin{array}{l}\text { Universality } \\
\text { entrepreneurs. }\end{array}$ \\
\hline 1.4 & What is the core contribution of entrepreneurs - the thing they do best and only they can do? & $\begin{array}{l}\text { Specialization } \\
\text { entrepreneurs. }\end{array}$ \\
\hline
\end{tabular}

1.5 In terms of venturing, are there areas or tasks entrepreneurs should be less or more involved Specialization and efficiency in?

1.6 Are entrepreneurs efficient in what they do? Do you think entrepreneurs sometimes waste time Efficiency of entrepreneurs. and resources? How?

1.7 Do you think there are minimum requirements to being an entrepreneur? Kindly motivate.

$\begin{array}{ll}\text { Qualification } & \text { of } \\ \text { entrepreneurs. }\end{array}$

1.8 What are some of the things entrepreneurs learn - expectedly or unexpectedly - during venturing?

Development of entrepreneurs.

1.9 Do you think entrepreneurs develop? If so, in what way, and how does it benefit them?

Development entrepreneurs.

1.10 Do you think the systems and processes organizations typically favour and develop would generally benefit or restrict entrepreneurs?

Efficiency and managability of entrepreneurs.

1.11 Can you think of systems and processes that you would like to see be developed, that would Efficiency of entrepreneurs. benefit entrepreneurs?

1.12 What motivates entrepreneurs the most? Do you think eventually owning the organization is Managability the biggest motivating factor for entrepreneurs?

entrepreneurs. 


\section{The organization of entrepreneurs}

2.1 Do you think investors and venture capitalists as role player can hinder the entrepreneur Organization types and funding. during opportunity perusal?

2.2 Given the organization types - independent entrepreneur, network, organization, Organization types and funding. corporation - what is the best way to organize entrepreneurs with regards to funding?

2.3 What (type of) resources are important for entrepreneurship?

2.4 Is ready access to data, knowledge and information important for entrepreneurship? Organization types and resources.

Organization types and resources, opportunity.

2.5 Given the organization types - independent entrepreneur, network, organization, Organization types and resources. corporation - what is the best way to organize entrepreneurs with regards to resources?

2.6 Do you think opportunity indentification and pursual benefit from groups of professional and leaders, like one would find in organizations, and so forth?

2.7 Given the organization types - independent entrepreneur, network, organization, corporation - what is the best way to organize entrepreneurs with regards to opportunity recognition and development?

2.8 Do you think entrepreneurs must necessarily run and own their ventures?

Organization types and opportunity.

Organization types and opportunity.

Organization types and risk, reward

2.9 Given the organization types - independent entrepreneur, network, organization, Organization types and risk, corporation - what is the best way to organize entrepreneurs with regards to risk and reward. reward?

2.10 In your view, can entrepreneurs and ventures in their early stages be pulled into Corporations as organization type. corporations?

2.11 Would you recommend that entrepreneurs participate in a corporation as an umbrella or Corporations as organization type. parent company?

2.12 In your view, what is the best way to organize entrepreneurs? On their own, as part of a Organization of entrepreneurs. network, within organizations, or as part of a corporation?

2.13 In your view, what type of organization would entrepreneurs favour? On their own, as part Organization of entrepreneurs. of a network, within organizations, or as part of a corporation?

\section{Analysis}

Below, the transcribed interviews:

Q 1.1: Do you think that, given the necessary resources, entrepreneurs will always be able to create economic products or ventures in the end? Can entrepreneurs repeatedly venture and innovate? A number of interviewees made a distinction between entrepreneurs and real entrepreneurs - different types of entrepreneurs and different levels of entrepreneurship. It was also mentioned that the statistical failure rate of start-up companies is a fact that can not be overlooked. The maturity and experience of the entrepreneur, and the capabilities of the entrepreneur (their level of creativity, commitment and initiative) were surfaced - whether the entrepreneur is still novice or already established.

Resources were mentioned as a necessary factor of growth and venturing, but not a sufficient factor; it does not guarantee proper decision-making. True entrepreneurs will always use the resources available to them, and will attempt to innovate or venture with the resources available to them, within the environment they find themselves in. Even without the necessary resources, entrepreneurs will still attempt to innovate. They will make a plan to advance their opportunity or venture, and true entrepreneurs will always find a way. A lot of ideas are born from a crisis, and entrepreneurs excel at overcoming crises. Still, the exent or rate of their entrepreneurial output may be limited by what is available to them at that point in time.

Entrepreneurs were also contrasted with mere business owners. Entrepreneurs as business owners start off, but show little operations growth or improvement (the way things are done) over time. What differentiates entrepreneurs are their ability to innovate and recognize opportunities. By definition, a true entrepreneur can constantly change, identify and (realize how to) solve problems, and see gaps in the market. They are able to start up multiple businesses successfully, create a management team to run the self-sustainable business, so that the entrepreneur can exit and move on to the next opportunity. Entrepreneurs must be able to bridge the gap between ideas and solution. Market intelligence (supply factors, competitors, etc) is identified as a crucial factor. One view was that market insiders that are close to market operation have access to the most opportunities. The entrepreneur must be involved or engaged to be ready or prepared to recognize - able to perceive - an opportunity.

Q 1.2: Should their current opportunity fail, can entrepreneurs easily identify new opportunities? It was noted 
that most successful entrepreneurs failed at some point. Failure can actually develop an entrepreneur to become more successful. The quality of not giving up contributes to the success of entrepreneurs. The mindset of an entrepreneur is to identify opportunities, rather than to sit and wait for something to come his way. What differentiates an entrepreneur is the ability to continuously find new ways of doing businesss or venturing. Entrepreneurs constantly think of new ideas and have developed the appropriate way of thinking to do this. Because of this, entrepreneurs hardly run out of ideas. They usually ponder multiple ideas at a time. Should one idea fail, other ideas immediately fill the gap.

Furthermore, tools like the internet and the global business environment enables information and (additional) opportunities, in that ideas are not bound to local markets. Still, technicalities like market intelligence, and so forth may influence the feasibility of new opportunities identified, and may influence the entrepreneur's success. It also depends on the abilities and skill of the entrepreneur, and the amount of effort the entrepreneur puts in.

Q 1.3: Are entrepreneurs bound by industry? If the entrepreneur is moved from one industry to another, will the entrepreneur be able to venture again, given sufficient time and resources? The central view is that certain entrepreneurial competencies and aspects are universal, whilst others are not. Character triats like willingness and drive to succeed that empowers entrepreneurship are universal. This also holds for competencies like opportunity identification, problem solving, and idea monetizing. Entrepreneurial resources like networks, skills and knowledge may be local to an industry. It may take time to again build up necessary resources that are not global. Some entrepreneurs are more in tune with, and fit for, certain industries than others, and because of this they will be more successful in certain industries.

Other views are that it is not necessarily required of the entrepreneur to manage the eventual business, and the entrepreneur builds on people that specialize in the industry, and that are better in the industry than him. The entrepreneur's main role is to give vision and direction to the industry. Also, entrepreneurs may merely need to excel in a particular aspect - for instance, understanding the supply side of business (designing systems and processes) - in order to be able to innovate and venture across industries. In addition, there are benefits and advantages in staying in a particular industry, such that it can be advantegous to become embedded and entrenched in an industry.

Q 1.4: What is the core contribution of entrepreneurs - the thing they do best and only they can do? The character and skills of entrepreneurs came up: the fact that they are driven, self-motivated, not afraid of problems or failures, prepared to take risks, ambitious, their ability to organize and prioritize, their ability to face problems and adversity, and their problem solving abilities. Their core competency is the ability to identify gaps in the market and to identify methods by which it can be filled. They do not truly need to manage the new operation or solution thereafter. Entrepreneurs bring order to chaos and uncertainty, and think out of the box, and in new ways. They challenge the status quo and think without boundaries or prescriptions.

One respondent divided the concept of business into four levels - personal (individuals and their personalities), functional (technical workers), operational (managers), strategic - and argued that the strategic level forms the highest level, the level where the vision of the company is determined, and the level where the entrepreneur contributes and functions. Other interesting responses are that entrepreneurs also cause others to think differently about things - they make them asks questions. Furthermore, they inspire other entrepreneurs.

$Q$ 1.5: In terms of venturing, are there areas or tasks entrepreneurs should be less or more involved in? Management, operations and administration are core aspects mentioned that entrepreneurs should be less involved in. The entrepreneur is depicted as the visionary or strategic person that should not be involved in day-to-day activities and management. Entrepreneurs should work on the business, not in the business, and should focus on improving and growing the business, and on the needs of the business as it grows. The ideal mentioned is that the entrepreneur should spend $80 \%$ of his time on the strategic level and $15 \%$ and $5 \%$ on the operational and functional level, respectively. However, during new venture inception, this may not realize.

Particularly when the venture is in its early stage, and depending on the funding the entrepreneur receives or does not receive, the entrepreneur typically may trade his time as resource for the ability to pursue his opportunity. Thus, the entrepreneur may take on a number of functional roles, including marketing, operations, management and administration, to get the opportunity and venture off the ground, and this may be non-economical and contrary to his area of speciality and expertise.

One respondent noted that entrepreneurs can pay more attention to relationships and networking, because of the benefits accrued this way.

Q 1.6: Are entrepreneurs efficient in what they do? Do you think entrepreneurs sometimes waste time and resources? How? Factors mentioned that contribute to the efficiency of entrepreneurs are qualification (education), including business qualification, experience, and skills acquired from past experience and their background. Other 
factors that make the entrepreeur efficient are fixed habits and routines, with the ability to distinguish between what is important, and what is not. Also, coherency and consistency - task prioritization and the ability to focus on a number of individual, core tasks at a time. Entrepreneurs may get stuck on a functional level for too long, and may waste time by attempting to do things themselves, instead of utilizing people better than them at that particular task. Circumstances, practicalities and so forth may force the entrepreneur to step out of his area of competency and speciality to address issues that are non-crucial to his role of venturing, but that are still necessary in order to actually move the opportunity and venture forward, for example, administrative and management duties like registering the business and attending to personnel issues.

Factors like the character of the entrepreneur and his core motivation may also be influential. They may be motivated or driven to focus on certain aspects, and neglect others. For example, given his background, the entrepreneur with an engineering background may overly focus on the supply side, in neglect of the demand side. Entrepreneurs tend to avoid the areas they are unfamiliar with, which actually creates inefficiencies and problems. They may overly focus on their passions, and neglect getting things done. Also, entrepreneurs may lack knowledge of or have misconceptions about funding, business and economy, or may simply have a different mentality of focusing on succeeding instead of attempting to be economical whilst doing it, leading to resources being wasted.

The organizational setup may determine how agile, flexible and efficient the entrepreneur and venture can be. Smaller organizations may have less overhead and may allow the entrepreneur to progress faster.

Q 1.7: Do you think there are minimum requirements to being an entrepreneur? Kindly motivate. A number of the respondents actually had a contrary view of the contribution of education to entrepreneurship. Tertiary education does not necessarily correlate with being dynamic and innovative. It is pointed out that entrepreneurship may be an inherit ability and may be born out of necessity, such that education hardly comes to play. Qualification can contribute to the entrepreneur's skills, knowledge and thinking. At the same time, depending on the individual, qualification may also box thinking. It is noted that knowledge and experience are accumulated along the way. Entrepreneurs can even learn how a business works along the way, such that business knowledge is not necessarily required.

Particular skills mentioned are skills pertaining to opportunity identification. By implication, these type of skills are not necessarily high-level or sophisticated. Another basic skill is the ability to start something (a venture). Also, the ability to carry strategic or holistic views.

Certain types of personality may be conducive to entrepreneurship. As part of personality, the unique, personal orientation of the entrepreneur was depicted - his personal motivation and drive, knowing that he will have to work hard, high stress tolerance, not being sensitive to others' opinions, the willingness to take risks, and willingness to act upon and interrogate opportunities.

Age also surfaced as factor. This is taken to proxy personal maturity.

$Q$ 1.8: What are some of the things entrepreneurs learn - expectedly or unexpectedly - during venturing? Entrepreneurs learn about themselves - their strengths and weaknesses - and their vantage point on life. They also improve professional skills particular to entrepreneurship, like their ability to understand and take risks, their ability to deal with failure, their interaction with others, their negotiation and opportunity marketing skills, leadership skills, planning and organizational skills, and venturing skills (putting down systems and processes).

Entrepreneurs develop their way of thinking: thinking more critical and questioning things, for example ideologies, policies and legislation. Entrepreneurs learn to become more realistic about opportunities and ventures, and to better manage their goals and expectations. Entrepreneurs learn to handle critique, and to be practical about goals, progress and achievement, and to consider and manage the interests and objectives of other stakeholders, like investors.

Entrepreneurs develop their ability to manage and handle adversity, problems, and unexpectancies, and operational failure. They learn (about) the industry they operate within, how to get a venture of the ground, and how to run a business successfully. There is equally learning involved in innovation and solving problems - as they solve problems, they learn more about the problem and how it can be solved. Entrepreneurs learn to delegate work - to show and teach others what they must do and how to do it. As part of leadership skills, they learn (how) to develop teams as well as team members. Entrepreneurs get exposed to every aspect of the business - from operations to marketing - and move from a position of approaching the business from a favourite vantage point, like marketing, to approaching the business holistically - as a whole.

Q 1.9: Do you think entrepreneurs develop? If so, in what way, and how does it benefit them? A part of entrepreneurial ability is biological or genetical through personality that is more consistent. At the same time, a part of entrepreneurial ability develop with time. Entrepreneurs develop their skills and knowledge, including their knowledge of themselves. 
Entrepreneurs learn from their past experiences and failures, and improve and develop this way. Entrepreneurs develop in their thinking and mental dispositions and vantage points. Entrepreneurs learn to become more strategic in thinking, and become better at putting ventures on the ground. They become more business competent, better at negotiating, and needs-sensitive, particularly those of investors, and this in turn open new opportunities and avenues to them. In general, they become better at approaching opportunities and ventures holistically.

Also, they learn about the problem and the solution while they innovate, thereby learning about better solutions and different opportunities.

An interesting point raised is that entrepreneurial skills and knowledge can also disseminate among entrepreneurs entrepreneurs can learn from each other. In addition, one view was that entrepreneurship in general amounts to a very steep learning curve - the more limited the resources available to the entrepreneur, the steeper the learning curve.

Q 1.10: Do you think the systems and processes organizations typically favour and develop would generally benefit or restrict entrepreneurs? The contrast between red tape and flexibility is surfaced. Red tape is not necessarily discarded straightaway as redundant and unnecessary, and still seen as relevant, and it is stated that there is a place for it. The objection is when red tape overly restrict venturing. A healthy balance between red tape and flexibility is advocated. It is also noted that even startups require an amount of systems and processes, particularly to free the entrepreneur, to direct employees, and to (begin to) steer the culture and values of the business. Systems and processes also allow the business to be scaled. Processes must be kept lean and must be necessary - have a function and purpose. Too much process may slow the entrepreneur down, and limit his speed of innovation. The view is that it should be possible to develop the systems and processes specifically for entrepreneurs and with entrepreneurship in mind.

In addition, the impact of organization on entrepreneurship is noted. The nature of the organization may inhibit entrepreneurship, particularly when the organizational focus is maintaining the organization, and this may also imply the status quo. Even if corporate governance is such that it does not hinder entrepreneurship, it may do little to encourage it. Entrepreneurs may have a negative disposition towards too much bureaucracy. The actual way the organization do things can restrict them.

Q 1.11: Can you think of systems and processes that you would like to see be developed, that would benefit entrepreneurs? Some of the things mentioned are customer relationship management (CRM) systems; email marketing; tools that help the entrepreneur to plan and prioritize, and to track his progress; budgeting, forecasting, and costing tools; innovation hubs for employees to share ideas; and free networking opportunities for entrepreneurs. CRM systems received a lot of votes. This helps to manage clients and potential clients. It is further benefitial when it is combined with email marketing. The view is that a hollistic, all-inclusive product does not exist, and it would be welcomed.

It is also noted that entrepreneurs equally design their own systems and processes, as a lot of things they do have not been done before. Mostly, entrepreneurs depend on their own systems and processes. Most of the systems and processes that entrepreneurs use are systems and processes that they come up with. On occasion, they innovate certain systems and processes to improve their businesses.

Systems and processes were also related to leadership and the function of leadership. Leadership should champion and drive the development of systems, processes, and culture conducive to entrepreneurship, particularly in the corporate environment. One specific aspect mentioned that can be further developed is the organization allowing entrepreneurs to fail, because they realize a certain degree of failure is inevitable. Furthermore, systems and processes that aid with the management of the company, were suggested, particularly from a cultural and strategic perspective, and from a startup perspective - systems and processes that also improve communication within the organization and that help to articulate the vision of leadership and the organization.

Q 1.12: What motivates entrepreneurs the most? Do you think eventually owning the organization is the biggest motivating factor for entrepreneurs? Personal accomplishment - the ability to say you built (and own) the company is raised as a factor, but not necessarily a key factor. True entrepreneurs would rather seek expression or self-actualization and thus would want to continually innovate, rather than manage. They would more readily move on to the next venture, such that venturing is more important than owning organizations. Personal expression can also take the form of freedom - the entrepreneur being in greater control of his destiny and time, and using his organization merely to express his personality and tastes and to attain his goals.

Furthermore, entrepreneurs' motivation may shift with time and success, and may move from material rewards - money and financial freedom - to more abstract rewards, like being successful and being an influence - shaping industries and the world they live in. Entrepreneurs tend to discover and realize their potential, and then set out to reach it, and even to push this boundary. Success and being successful is seen as a core motivator.

Q 2.1: Do you think investors and venture capitalists as role player can hinder the entrepreneur during 
opportunity perusal? It is noted that availability of funding is the greatest impediment to entrepreneurship - even exceptional entrepreneurs would fail without funding. In many cases, entrepreneurs need investors and are dependent on them. The view is that investors provide some guidance, and also restrictions. If investors hinder entrepreneurs, it is not always in a bad way. In a sense, investors are entrepreneurs or entrepreneurial too, and may have a lot of common ground with entrepreneurs. On certain grounds, in certain cases and on certain issues, investors and entrepreneurs differ in opinion and motivation. Ideas are evaluated based on a portfolio of aspects and criteria. Sometimes investors and entrepreneurs can not find common ground in this regard, as the investor wants a different mix for the same idea, with the entrepreneur failing to see how it would be possible. Investors may view ideas from a different vantage point, and perhaps in a more detached way. A key criterion for the investor may be risk exposure, whereas it is not necessarily the same for the entrepreneur. What would make the venture suit the investor may not always agree with what the entrepreneur perceives would make the venture work.

Investment is depicted as an ongoing process and relationship. The investor becomes involved, and wants to be kept abreast with developments, and may respond differently to adversities and unexpectancies arising during venturing, and typical of venturing. Drivers of motivation of investors and entrepreneurs are important and can differ. The entrepreneur also exposes himself during investment in that he must put his plans on the table, with little guarantee of security, and must accept additional input and more collective decision-making. The team may steer the venture in a way different from what the entrepreneur foresaw, and synergy and collaboration among the team are crucial for venture success. Good chemistry between the members of the now broader leadership team - the entrepreneur, investors and so forth - is essential.

It also depends on the experience and maturity of the investor, and investors may differ across geographical regions. Investors may shy away from risky ventures, and entrepreneurs and investors may not always share the same risk appetite or mindset towards risk. However, more experienced investors understand the nature of entrepreneurship, how to approach risk, and the nature and statistics of failure and success. Some of the aspects on which investors may differ are: risk perceptions and approaches, acceptance and approach to failure, and required guarantees of return on investment. Failure may be more fatal in certain regions than others. Investors' evaluation of guarantee of return on investment may also differ, to the extent that investors may choose to not invest in a project without a guarantee of return on investment beforehand, which may be a constraining approach.

Q 2.2: Given the organization types - independent entrepreneur, network, organization, corporation - what is the best way to organize entrepreneurs with regards to funding? In certain cases, speed of innovation is a determining factor. Independent entrepreneurs enjoy the most freedom and are the fastest. Large organizations have the appropriate funding, but may have too much red tape and can be slow. A collaborate environment helps the entrepreneur to be effective, as entrepreneurs challenge each other, bring different skills to the table, and share experiences. Institutions have the best vision (understanding) and sense of direction, of industries. For these reasons, networks within corporations are also seen as better than networks in some cases.

Depending on the composition, networks can consist of experts, and thus provide access to experts and expert skills. In addition, networks may also be more social or humanistic in nature, and less professional, with opportunities evaluated on different grounds than with institutions, with greater emphasis on trust, friendship, collaboration, and the entrepreneur as person. This implies a different vantage point on risk, and may better suit the entrepreneur.

A particular setup frequently referred to is corporate venturing - large organizations enabling entrepreneurship in small organizations. Smaller organizations with diverse skill sets can be dynamic and fast, with far less red tape. In essence, a corporation that aims for both freedom and funding. The setup may be better at enabling venturing. The entrepreneur is guided in terms of current problems, shortcomings and difficulties faced, and is enabled in terms of funding and other resources. The entrepreneur then (merely) serves as the catalyst that enables the problem or difficulty to be overcome.

The setup may depend on the venture. Institutions have existing cash flow and revenue streams, that helps to difersify the risk of venturing, which may be attractive in particularly risky ventures. Individuals may find it difficult to obtain funding, and may thus be pushed into organizations, altough networks can help in this regard. The setup may also depend on the entrepreneur and his level. Put differently, the level of the entrepreneur may determine his setup. Experienced, resourceful entrepreneurs may choose to venture independently. Inexperienced entrepreneurs may be compelled to turn to institutions.

Q 2.3: What (type of) resources are important for entrepreneurship? Financial resources are seen as very important, for obvious reasons. Knowledge, skills and expertise were also noted. Knowledge includes market intelligence, and also entails knowledge outside of the area of expertise or specialization the entrepreneur may have. Skills include business acumen, as well as knowledge gathering and accumulation related to opportunities as skill; also the ability to attract, engage investors, and sell ideas to them. Reputation - being known as entrepreneur and by investors - was also 
mentioned. Human resources received a lot of attention: actual human resources; mentoring and (business) coaching, including peer to peer; and support networks - unbiased support and help (social networks and support groups serving as friends or companions).

Q 2.4: Is ready access to data, knowledge and information important for entrepreneurship? The types of knowledge and information sought and researched include: technology, resources, trends, state of economies and economic trends, competing products, and competition. Additional points mentioned were: finding out how others solve a particular problem; understanding risk implications; and market related information - inside market information, and market culture (the culture of the people comprising a market). Sources of knowledge and information were: the internet; market incumbents and competitors; business coaches and mentors; autobiographies; and simply being in the market. Being in the market was also seen as an important enabling factor, and the threat of information overload was surfaced.

Q 2.5: Given the organization types - independent entrepreneur, network, organization, corporation - what is the best way to organize entrepreneurs with regards to resources? The abundant and theoretically readily available resources of institutions, with the impediments they bring, were mentioned. Networks received a lot of support. This covered networks consisting of or implying friends helping friends, external networks of coaches and experts structured around industries, also networks within organizations that aid resource and knowledge sharing. It is also noted that organizations possess industry specific knowledge and skills.

Q 2.6: Do you think opportunity indentification and pursual benefit from groups of professionals and leaders, like one would find in organizations, and so forth? Some see opportunity identification as better in organizations. The view is also that networks can help with opportunity identification. Groups help to retain focus and perspective, and provide information and advice. Yet, the individual received a lot of votes. Organizations may have abundant resources, including knowledge residing in their employees, in turn including knowledge of opportunities. Being part of an organization can equally blind the entrepreneur and limit his thinking and flexibility. Opportunities are equally found by exiting the organization to look for opportunities. Few institutions create an environment for entrepreneurs to flourish. Organizations do not always commercialise on opportunity. Organizations may have access to more opportunities, as merely ideas, due to the volume of employees and participants. Yet, the view is that individuals tie the knot individuals tend to interrogate and work these opportunities. Also, organizations would struggle to service niche markets.

Q 2.7: Given the organization types - independent entrepreneur, network, organization, corporation - what is the best way to organize entrepreneurs with regards to opportunity recognition and development? The results were again divided in two camps - those for and those against institutions. In institutions, it may be much easier and quicker to identify opportunities or needs, and access risk. Networks may come with the benefits of institutions, without the pressure or additional burden of advice contrary to what the entrepreneur wants. Hierarchy and relationships are different in networks than institutions, and the type of advice the entrepreneur requires may differ from what he would get from the institution. Motivation and encouragement may be as valuable advice as professional views and opinions.

Q 2.8: Do you think entrepreneurs must necessarily run and own their ventures? It is important for the entrepreneur to be a part of the venture, as he is the one who carries the vision of the venture and the one who best understands the venture and its purpose. At a point however, he delegates and distances himself more and his role diminishes. Entrepreneurs should own a large portion of the business - at least $20-30 \%$. Wisdom is that the entrepreneur should not run his own venture, yet empirical evidence on successful ventures suggests otherwise. Most of the time, the entrepreneur can not learn all the business aspects fast enough in order to run the business, and he should retire to the strategic level or advisory board. The entrepreneur does not necessarily have the personality type and strengths to be the business owner. At the same time, the entrepreneur is a great source of motivation within the venture, and can not exit too early. Contrary to thinking, knowing he must hand over the venture to someone else may actually motivate the entrepreneur, as this places a time limit on him to make the venture successful.

Q 2.9: Given the organization types - independent entrepreneur, network, organization, corporation - what is the best way to organize entrepreneurs with regards to risk and reward? Collaborative environments minimize risk through sharing ideas and learning from others, yet a single person can not take credit for the work or the idea. Organizations are more formal, with less risk, and less reward for the entrepreneur. Networks are less formal and likely riskier, with greater reward. Networks are also mentioned in the context of competition - networks can allow the entrepreneur to better compete.

Reward can be thought of as both monetary reward accruing to the entrepreneur, as well as simply venture success and other non-monetary rewards. In many cases, reward to the entrepreneur receives more attention than entrepreneurial throughput. Risk minimization is also not necessarily portrayed as priority. It is seen that risk is part of the game, and 
the entrepreneur should have a basic appetite for risk. Reducing risk in the context of increasing entrepreneurial throughput did not really surface.

The conventional risk-reward relationship of high risk, high reward, is frequently referenced, and may point to a cliche. This is cited as a source of motivation, although it does not come across as a true motivator of entrepreneurs. The dominant mentality may be that, if entrepreneurs can assume the risk, they will be proportionally rewarded.

Q 2.10: In your view, can entrepreneurs and ventures in their early stages be pulled into corporations? From the perspective of the corporation, the overall driver to incorporate ventures into corporations is seen as specific skills the venture posseses, or the venture adding value to the parent company. The motivation is also acquisition cost - if the venture grows, it becomes more valuable and thus more expensive to acquire. The industry type is also noted as a factor, for example technical industries. A number of respondents argue that it may destroy the venture. Culture is seen as the greatest threat. Being pulled into a corporation with a different culture may stifle and hinder the entrepreneur and venture. The entrepreneur may lose his flexibility, speed, and efficiency. The recognized benefit is a transfer of risk from the entrepreneur to the corporation. The mentioned downside is the entrepreneur handling over his idea for reward or recognition or a role he does not necessarily desire or agree to.

Q 2.11: Would you recommend that entrepreneurs participate in a corporation as an umbrella or parent company? The benefits to this may be access to resources and the brand of the corporate. The way rewards are shared is seen as important. A reluctance surfaces, with a consideration of the implications in terms of sharing of rewards, and the level of association or attachment to the corporation is highlighted. An agreement in the form of a partnership was suggested. Other stipulations to make such an arrangement work are the culture and leadership the entrepreneur would be subjected to; also the vision and mission of the corporate. One respondent's view was that the entrepreneur would not get more from a corporation, that what he would get from a network.

\section{Q 2.12: In your view, what is the best way to organize entrepreneurs? On their own, as part of a network, within} organizations, or as part of a corporation?

The majority suggested networks. It is seen that networks can be rather successful, if the network is able to provide a lot of training and mentoring. A reason why this method of organization is seen as most appropriate is due to its informal basis. One interviewee depicted the entrepreneur's ideal world as an organization or corporate, with an entrepreneurial culture similar to that of a network: having a team of 10 to 15 people to work with, a culture that focus on innovation, and decent funding. Another view was that entrepreneurship originates from an individual or small group. The entrepreneur should only be given the necessary or most important resources to enable him. It was also seen as dependent on the stage the entrepreneur and idea are in. In one instance, their organization was also linked to reward, specifically financial reward.

Q 2.13: In your view, what type of organization would entrepreneurs favour? On their own, as part of a network, within organizations, or as part of a corporation? The overall view is that it depends on the type and personality of the entrepreneur. It is also noted that a true entrepreneur will not remain in an institution. The entrepreneur would have sufficient risk appetite to venture on his own, in favour of more freedom and flexibility. The entrepreneur may prefer a small organization that he can steer and develop.

\section{Conclusion}

There is sufficient evidence to suggest that, as resource, entrepreneurs are reliable - they are able to repeatedly innovate and venture. The primary reason for this are their ability to identify opportunities and solve problems, and their tenacity in this regard. The skills and capabilities, maturity and experience of the entrepreneur, and the resources, including knowledge, available to him, are factors that affect his reliability.

Entrepreneurs are also universal - they are not necessarily bound by industry. Certain entrepreneurial competencies are universal - character traits and competencies like opportunity identification and problem solving. Resources like networks, skills and knowledge may be local to an industry, may take time to build up again, and may thus localize the entrepreneur. At the same time, the entrepreneur may only need to be able to give vision to the industry, or possess a particular, exceptional skill or expertise to be universally successful.

By nature, entrepreneurs are problem solvers, engineers (that is, designers and builders), opportunists, and venturers. Their character, experience and skills allow them to specialize. Some of their core competencies and strengths include being self-driven, ambitious, and autonomous, prepared to take risks, not afraid of problems or failures, their ability to face problems and adversity, their problem solving abilities, and their ability to identify opportunities and solutions. Entrepreneurs provide vision, bring order to chaos and uncertainty, think out of the box, and in new ways, without boundaries or prescriptions, and challenge the status quo. Entrepreneurs should not be involved in management, operational, or administrative activities, as this is contrary to their area of specialitiy and non-economical. Yet, due to 
practicalities, this does not always realize. Qualification, experience, skills and background affects the efficiency of the entrepreneur. His background and level of experience may cause the entrepreneur to focus on the wrong objectives, to over-emphasize certain aspects, and to neglect others. Also, entrepreneurs may waste time by attempting to do things themselves. The organization the entrepreneur finds himself in, also determines how efficient the entrepreneur is.

Education does not qualify a person to be an entrepreneur per se. Tertiary education does not necessarily correlate with being dynamic and innovative. Qualification can contribute to the entrepreneur's skills, knowledge and thinking; at the same time, qualification may also box thinking. Knowledge and experience are accumulated along the way, and are not necessarily required from the onset. The primary qualifier of entrepreneurship are skills pertaining to opportunity identification, and certain types of personality may be conducive to entrepreneurship.

Entrepreneurs develop further with time. Altough things like their personality hardly change, their skills and knowledge develop. They learn more about themselves, and improve and develop their entrepreneurial skills, professionalism, and thinking. Entrepreneurs also learn from their past experiences and failures, and from other entrepreneurs.

Within the context of improving the efficiency of entrepreneurs, in the right quantity, systems and processes can help and benefit the entrepreneur, and entrepreneurs only oppose this, when it starts to restrict their speed and flexibility. Systems and processes help to free the entrepreneur, direct the venture as organization, and to scale the venture. The view is that it should be possible to develop the systems and processes specifically for entrepreneurs and with entrepreneurship in mind. Entrepreneurs equally design their own systems and processes. Systems and processes are also related to leadership and the function of leadership - within institutions, it is up to leadership to create the right culture through the appropriate systems and processes.

Owning businesses is not a primay motivator for entrepreneurs; instead, self-actualization is a far more important motivation. Being successful is a key motivator, and greater freedom also motivates them. Entrepreneurs want to continually innovate. Entrepreneurs' motivation may shift with time and success, and may move from material rewards to more abstract rewards, like being successful and being an influence - shaping industries and the world they live in.

Funding is a significant factor of entrepreneurship, and equally signals belief and confidence in opportunities. The investor - also institutions or the organization the entrepreneur finds himself in - may provide both guidance and restrictions. Entrepreneurs and investors may approach opportunities and ventures with different perspectives, and it becomes a matter of finding common ground. Investors too may be unrealistic about ventures and their risk, and may wish to tailor, manage and steer a venture in such a way that it is no longer possible for the venture to succeed. The investor becomes involved, wants to be kept abreast with developments, and may respond differently to adversities and unexpectancies typical of venturing. Any ungrounded or imperfect risk adversity, risk perspective or risk management on the side of the investor may wreck the venture too, and investors do not have better risk perspective and management capabilities than entrepreneurs per se.

Investment culture becomes important. Investors may shy away from risky ventures, and may not always share the risk appetite or mindset towards risk of entrepreneurs. Also, investors' acceptance and approach to failure, and required guarantees of return on investment may vary. Investors' evaluation of guarantee of return on investment - for instance, choosing not to invest in a project without a guarantee of return on investment beforehand - may be a constraining factor to entrepreneurship. It may be necessary for institutions to develop a culture of allowing entrepreneurs to fail, because they realize a certain degree of failure is inevitable.

Other resources important for entrepreneurship are information and knowledge, skills, expertise, and human resources. Some of these resources may be embedded in industries, and the institutions of a particular industry.

Speed of innovation, and flexibility and freedom in innovation were noted as important factors of innovation success. Entrepreneurs may organize themselves accordingly. A collaborate environment helps the entrepreneur to be effective, as entrepreneurs challenge each other, bring different skills to the table, and share resources, experiences and knowledge. Groups help to retain focus and perspective, and provide information and advice. Institutions have the best vision (understanding) and sense of direction of industries. In institutions, it may be much easier and quicker to identify opportunities or needs, and access risk. Large organizations have the appropriate funding, and may be better at diversifying risk, but may have too much red tape and can be slow. In essence, large institutions may have all the resources required for entrepreneurship, but may struggle to exploit it and capitalize on it through ventures and venturing.

Networks too can consist of experts, be constructed around industry, and thus provide access to expert skills. In addition, given their informal basis, networks may also be more social or humanistic in nature, and less professional, with opportunities evaluated on different grounds than with institutions, with greater emphasis on trust, friendship, collaboration, and the entrepreneur as person. This implies a different vantage point on risk, and may better suit the 
entrepreneur. Networks may overcome issues around funding too, and may also aid with opportunity identification. Networks may come with the benefits of institutions, without the pressure or additional burden of advice contrary to what the entrepreneur wants. Hierarchy and relationships are different in networks than institutions, and the type of advice the entrepreneur requires may differ from that he would get from the institution. Networks can be rather successful, if the network is able to provide a lot of training and mentoring.

Corporate venturing - large organizations enabling entrepreneurship in small organizations was frequently championed. This may bring together and combine speed, flexibility, freedom and funding. The entrepreneur is exposed to and guided in terms of current problems, shortcomings and difficulties faced, and is enabled in terms of funding and other resources. The entrepreneur then (merely) serves as the catalyst that enables the problem or difficulty to be overcome. This form of organization can also overcome the issue of culture.

His personality, competencies and strengths, and motivations are not such that the entrepreneur necessarily needs to own what he creates, and the entrepreneur may be content with merely being allowed to act on opportunity and to venture. This implies entrepreneurs can be readily exploited as economical and societal resource, with perhaps less cost than believed.

The way rewards are shared, and the level and method of association or attachment to the corporation may also be significant impediments to organizing and incorporating entrepreneurs in organizations. Security can be an important motivator for the entrepreneur - he is expected to place his ideas on the table, gets tied up, and may get tied up in ways he does not desire. Furthermore, he must accept additional input and decision-making.

The relationship between entrepreneurial throughput and risk and reward may be overlooked, lacking substance, and subject to stereotypical thinking. In the context of entrepreneurial reward, entrepreneurial throughput is ignored, or it is generally assumed that entrepreneurial throughput is maximized through maximizing entrepreneurs' rewards, generally as a method to incentivize entrepreneurs. Risk minimization, particularly for the entrepreneur, is also not necessarily related to entrepreneurial throughput. Risk is part of the game, and the entrepreneur should have a basic appetite for risk. Yet, an orthodox view of the relationship between risk and reward - high risk, high reward - is frequently referenced and accepted. The entrepreneur is willing, motivated, and left or compelled to assume high - also sole - risk and responsibility, with the view, mindset and vision in mind that high risk can bring high reward. This occurs when neither risk nor reward are principal motivators for the entrepreneur per se - the entrepreneur is willing to take risk, but is not motivated by risk, and the entrepreneur welcomes reward, but, compared with the opportunity to venture, reward is not necessarily his primary motivator. This depiction of entrepreneurship as a high-stakes game, may be due to entrepreneurial culture - the entrepreneur is seen and depicted as champion and lone ranger and naturally expected to shoulder high risk and responsibility - or limitations emanating from funding - the entrepreneur being forced to assume high risk, because of funding. Entrepreneurship should best transition to a more balanced game.

From the study, a number of factors and deficiencies can be listed that impact entrepreneurial output. In light of this, a number of constructs and measures pertaining to entrepreneurship can be suggested: i) entrepreneurial emergence - the method used to identify entrepreneurs, and the rate at which new entrepreneurs are identified; ii) entrepreneurial development - the growth and development of known entrepreneurs; iii) entrepreneurial longevity - the reuse and lifespan of entrepreneurs; and iv) the evaluation of entrepreneurs. Attention could be given to the method and success rate of identifying entrepreneurs. Entrepreneurs needing to prove themselves first to be recognized may be an inefficient method of sourcing entrepreneurs. Attention can also be given to the development of known entrepreneurs - how can the skills, experience and knowledge of entrepreneurs be best developed, and how well are entrepreneurs developed? Also, what is the longevity and utilization of entrepreneurs - what is the holistic lifespan of entrepreneurs and how well are entrepreneurs utilized and reused, when also considering entrepreneurs that were overlooked, or that fell away due to failure, policies towards failure, and the knowledge and resources contained in entrepreneurs that fall away when they fail? In light of the above points, the performance appraisal of entrepreneurship may be revised.

In this context, institutions may be best geared for entrepreneurship and to maximize entrepreneurial throughput, conditional on appropriate culture and entrepreneurial willingness. Institutions have the necessary resources, are industry-local, and may be best able to manage entrepreneurs as resource. Corporations building on entrepreneurship as competitive advantage may be confined to entrepreneurs and ventures not greatly dependent on industry, particularly if the entrepreneur builds and must build extensively on the industry. Overall, it may be a case of firing with all cannons utilizing all methods of organizing entrepreneurs, in the right proportion, and ensuring certain avenues are not neglected.

The interaction between entrepreneurs and the needs of entrepreneurs were also important dynamics that surfaced. Some of the specific needs of entrepreneurs is actually unbiased support, which they would unlikely find from their professional environment, and for this reason entrepreneurs make extensive use of support networks or "entrepreneurial 
fraternities". Also, entrepreneurs interact with each other on a large scale, and entrepreneurs influence, mentor, advise, support, motivate, and shape each other. Motivation and encouragement may be as valuable advice as professional views and opinions.

A pressing question is whether it would indeed be possible to institutionalize entrepreneurship, mostly through legislation that require organizations to spend a percentage on entrepreneurship. The thinking is that, even if organizations initially see it as a cost that should merely be written off, they would sooner or later move to attempt to maximize the return, given that it actually is not a cost at all - the organizations would sooner or later consider and attempt to maximize the entrepreneurial output from this investment, one way or the other.

\section{References}

Amit, R., Muller, E., \& Cockburn, I. (1995). Opportunity costs and entrepreneurial activity. Journal of Business Venturing, 10(2), 95-106. https://doi.org/10.1016/0883-9026(94)00017-O

Ardichvili, A., Cardozo, R., \& Ray, S. (2003). A theory of entrepreneurial opportunity identification and development. Journal of Business Venturing, 18(1), 105-123. https://doi.org/10.1016/S0883-9026(01)00068-4

Austin, J., Stevenson, H., \& Wei - Skillern, J. (2006). Social and commercial entrepreneurship: same, different, or both? Entrepreneurship Theory and Practice, 30(1), 1-22. https://doi.org/10.1111/j.1540-6520.2006.00107.x

Barrett, R., \& Mayson, S. (2007). Human resource management in growing small firms. Journal of Small Business and Enterprise Development, 14(2), 307-320. https://doi.org/10.1108/14626000710746727

Barringer, B. R., \& Bluedorn, A. C. (1999). The relationship between corporate entrepreneurship and strategic management. Strategic Management https://doi.org/10.1002/(SICI)1097-0266(199905)20:5<421::AID-SMJ30>3.0.CO;2-O

Chrisman, J. J., Bauerschmidt, A., \& Hofer, C. W. (1998). The determinants of new venture performance: An extended model. Entrepreneurship Theory and Practice, 23, 5-30.

Cogliser, C. C., \& Brigham, K. H. (2004). The intersection of leadership and entrepreneurship: Mutual lessons to be learned. The Leadership Quarterly, 15(6), 771-799. https://doi.org/10.1016/j.leaqua.2004.09.004

Cohen, A. R. (2002). Mainstreaming corporate entrepreneurship: leadership at every level of organizations. Babson Entrepreneurial Review, 5-15.

Corbett, A. C. (2005). Experiential learning within the process of opportunity identification and exploitation. Entrepreneurship Theory and Practice, 29(4), 473-491. https://doi.org/10.1111/j.1540-6520.2005.00094.x

Cunningham, J. B., \& Lischeron, J. (1991). Defining entrepreneurship. Journal of small business management, 29(1), 45.

Das, T. K., \& Teng, B. S. (1997). Time and entrepreneurial risk behavior. Entrepreneurship: theory and practice, 22(2), 69-71.

Dickson, P. R., \& Giglierano, J. J. (1986). Missing the boat and sinking the boat: A conceptual model of entrepreneurial risk. The Journal of Marketing, 58-70. https://doi.org/10.2307/1251585

Eyal, O., \& Kark, R. (2004). How do transformational leaders transform organizations? A study of the relationship between leadership and entrepreneurship. Leadership and Policy in Schools, 3(3), 211-235. https://doi.org/10.1080/15700760490503715

Gaglio, C. M., \& Katz, J. A. (2001). The psychological basis of opportunity identification: Entrepreneurial alertness. Small business economics, 16(2), 95-111. https://doi.org/10.1023/A:1011132102464

Gartner, W. B. (1985). A conceptual framework for describing the phenomenon of new venture creation. Academy of management review, 10(4), 696-706.

Goold, M., \& Campbell, A. (1991). Corporate Strategy and Parenting Skills, Research Report, Ashridge Strategic Management Centre

Hayton, J. C. (2005). Promoting corporate entrepreneurship through human resource management practices: A review of empirical research. Human Resource Management Review, 15(1), 21-41. https://doi.org/10.1016/j.hrmr.2005.01.003

Herbst, D., \& Barnard, B. (2016). Innovation Management in South Africa: An Inquiry. Journal of Management and Sustainability, 6(3), 34-43. https://doi.org/10.5539/jms.v6n3p34

Hidalgo, A., \& Albors, J. (2008). Innovation management techniques and tools: a review from theory and practice. $R \& d$ 
Management, 38(2), 113-127. https://doi.org/10.1111/j.1467-9310.2008.00503.x

Huntsman, B., \& Hoban Jr, J. P. (1980). Investment in new enterprise: Some empirical observations on risk, return, and market structure. Financial Management, 44-51. https://doi.org/10.2307/3665167

Ireland, R. D., Covin, J. G., \& Kuratko, D. F. (2009). Conceptualizing corporate entrepreneurship strategy. Entrepreneurship theory and practice, 33(1), 19-46. https://doi.org/10.1111/j.1540-6520.2008.00279.x

Lado, A. A., \& Wilson, M. C. (1994). Human resource systems and sustained competitive advantage: A competency-based perspective. Academy of management review, 19(4), 699-727.

Lewis, G, Morkel, A., Hubbard, G., Davenport, S., \& Stockport, G. (1999). Australian and New Zeeland strategic management: concepts, context and cases; $2^{\text {nd }}$ edition; Prentice Hall; ISBN 0-7248-1131-1

Liao, S. H., \& Wu, C. C. (2010). System perspective of knowledge management, organizational learning, and organizational innovation. Expert systems with Applications, 37(2), 1096-1103. https://doi.org/10.1016/j.eswa.2009.06.109

MacMillan, I. C., Siegel, R., \& Narasimha, P. S. (1985). Criteria used by venture capitalists to evaluate new venture proposals. Journal of Business venturing, 1(1), 119-128. https://doi.org/10.1016/0883-9026(85)90011-4

Mintzberg, H., Ahlstrand, B., \& Lampel, J. (1998). Strategy Safari; Pearson International; ISBN-13: 978-0-273-65636-4

Morris, M. H., \& Jones, F. F. (1993). Human resource management practices and corporate entrepreneurship: an empirical assessment from the USA. International Journal of Human Resource Management, 4(4), 873-896. https://doi.org/10.1080/09585199300000062

Mullins, J. W., \& Forlani, D. (2005). Missing the boat or sinking the boat: A study of new venture decision making. Journal of Business Venturing, 20(1), 47-69. https://doi.org/10.1016/j.jbusvent.2003.08.001

Nicolaou, N., \& Birley, S. (2003). Academic networks in a trichotomous categorisation of university spinouts. Journal of Business Venturing, 18(3), 333-359. https://doi.org/10.1016/S0883-9026(02)00118-0

Palich, L. E., \& Bagby, D. R. (1995). Using cognitive theory to explain entrepreneurial risk-taking: Challenging conventional wisdom. Journal of business venturing, 10(6), 425-438. https://doi.org/10.1016/0883-9026(95)00082-J

Peredo, A. M., \& McLean, M. (2006). Social entrepreneurship: A critical review of the concept. Journal of world business, 41(1), 56-65. https://doi.org/10.1016/j.jwb.2005.10.007

Pycraft, M., Singh, H., \& Phihlela, K. (2004). Operations Management - South African Edition; Pearson Education South Africa; 1-86891-070-9

Rice, M. P., O’Connor, G. C., Leifer, R., McDermott, C. M., \& Standish-Kuon, T. (2000). Corporate venture capital models for promoting radical innovation. Journal of Marketing Theory and Practice, 8(3), 1-10. https://doi.org/10.1080/10696679.2000.11501870

Schumpeter, J. (1934). Capitalism, socialism, and democracy. New York: Harper and Row.

Sharma, P., \& Chrisman, S. J. J. (2007). Toward a reconciliation of the definitional issues in the field of corporate entrepreneurship. In Entrepreneurship ( 83-103). Springer Berlin Heidelberg.

Shepherd, D. A. (1999). Venture capitalists' assessment of new venture survival. Management science, 45(5), 621-632. https://doi.org/10.1287/mnsc.45.5.621

Short, J. C., Ketchen Jr, D. J., Shook, C. L., \& Ireland, R. D. (2010). The concept of “opportunity” in entrepreneurship research: Past accomplishments and future challenges. Journal of Management, 36(1), 40-65. https://doi.org/10.1177/0149206309342746

Stevenson, H. H., \& Jarillo, J. C. (2007). A paradigm of entrepreneurship: Entrepreneurial management. In Entrepreneurship ( 155-170). Springer Berlin Heidelberg.

Tracey, P., \& Clark, G. L. (2003). Alliances, networks and competitive strategy: rethinking clusters of innovation. Growth and change, 34(1), 1-16. https://doi.org/10.1111/1468-2257.00196

Tyebjee, T. T., \& Bruno, A. V. (1984). A model of venture capitalist investment activity. Management science, 30(9), 1051-1066. https://doi.org/10.1287/mnsc.30.9.1051

Vecchio, R. P. (2003). Entrepreneurship and leadership: common trends and common threads. Human resource management review, 13(2), 303-327. https://doi.org/10.1016/S1053-4822(03)00019-6

Weerawardena, J., \& Mort, G. S. (2006). Investigating social entrepreneurship: A multidimensional model. Journal of 
world business, 41(1), 21-35. https://doi.org/10.1016/j.jwb.2005.09.001

Wright, P. M., \& McMahan, G. C. (1992). Theoretical perspectives for strategic human resource management. Journal of management, 18(2), 295-320. https://doi.org/10.1177/014920639201800205

\section{Copyrights}

Copyright for this article is retained by the author(s), with first publication rights granted to the journal.

This is an open-access article distributed under the terms and conditions of the Creative Commons Attribution license which permits unrestricted use, distribution, and reproduction in any medium, provided the original work is properly cited. 